\title{
Differentiated Instruction: The Effect on Learner's Achievement in Kindergarten
}

\author{
Mazen Kotob ${ }^{1}$, Doha Arnouss ${ }^{1}$ \\ ${ }^{1}$ Lebanese International University, Lebanon \\ Correspondence: Mazen Kotob, Lebanese International University, Lebanon.
}

Received: July 7, 2019 Accepted: August 13, $2019 \quad$ Online Published: August 26, 2019

doi:10.11114/ijce.v2i2.4479 URL: https://doi.org/10.11114/ijce.v2i2.4479

\begin{abstract}
Identifying an effective instructional strategy to help diverse learners reach their full potentials is a goal for educators. Differentiated instruction has received much attention as a possible strategy. The purpose of this quasi-experimental study was to examine the effect of incorporating differentiated instructional practices on students' achievement in the kindergarten classes. In this action research, the researcher sought to answer the following research question: Does incorporating differentiated instructional practices leads to significant increase in students' achievement in the kindergarten classes? Two kindergarten classes with 38 students and 2 teachers participated in the study; one was assigned to an experimental group who received differentiated instructional strategies for 3 weeks and the other one to the control group who received traditional teaching practices. Data was collected, analyzed and compared using SPSS and independent sample t-test. Results revealed that there was no significant difference in student achievement results between the differentiated and non-differentiated classrooms. Findings of this study highlight the necessity for further explorations on the effect of differentiated instructional practices on achievement results in the kindergarten classrooms.
\end{abstract}

Keywords: differentiated instruction, learner's achievement, kindergarten

\section{Introduction}

Kindergarten is a child's first experience into educational journey; it is the place where children explore their strengths, learning style, learning pace, and their very special kind of intelligence. Teachers are the ones responsible for helping children know and reach their learning needs. Thus, no one-size-fits-all approach has to be followed. "A systematic approach to planning curriculum and instruction for academically diverse learners" (Tomlinson \& Eidson, 2003, p. 3), referred to as differentiation, is crucial to provide a quality education while meeting students' different needs. Differentiated instruction is a successful teaching philosophy that aims to increase student's performance and engagement in the classroom (Beecher \& Sweeny, 2008; Brimfield, Masci, \& DeFiore, 2002; Cusumano \& Mueller, 2007; Mastropieri et al., 2006; Rock, Gregg, Ellis, \& Gable, 2008; Tieso, 2001).

Modern educational systems are facing core problem regarding educational effectiveness; they are failing in delivering quality and equity among different groups of students, which leads to an achievement gap between them (Brooks-Gunn \& Duncan, 1997; De Civita, Pagani, Vitaro, \& Tremblay, 2004; Strand, 1999). Evidence supports that achievement gap increases during schooling (Fryer \& Levitt, 2004, 2006).

Traditional approaches are one of the basic reasons behind this problem since they do not focus on facilitating learning for all students who exist in the same classroom (Valiande, 2010). Effective educational strategies are guided by the differentiated instruction approach. This is what supporters of differentiation believe (Tomlinson, 1999, 2001; Koutselini, 2006).

This project is all about an effort to put differentiation in practice by following the guidelines of effective differentiated instruction and evaluating its implementation and its effectiveness aiming to find a way to reach all students.

The information presented in this research will provide teachers with further information about the differentiated instruction approach and its effectiveness on students' achievement. Teachers will be encouraged to differentiate if it was proven that differentiated instruction has a positive effect on students' achievement. If not, they will recognize it does not have any negative effect on students' achievement but reflects quality educational practices.

The findings of this study may change the way universities prepare students to become educators and may change the 
topics of professional development opportunities offered by administrators for teachers. If research results were positive, it may help parents and community stakeholders by attending differentiated instruction workshops related to classroom practices clarifying if such practices help in closing the achievement gap.

To this end, the study of the effects of differentiated instruction on students' achievement would be important to teachers, administrators, parents and community stakeholders.

When implemented into existing curriculum, differentiated instruction practices were able to improve the performance of all students (Fisher, Frey, \& Williams, 2003; Lewis \& Batts, 2005; McTigue \& Brown, 2005; Nugent, 2006; Walker, 2002). Some studies believed that the teacher's dedication to find unique learning styles of students enables a successful integration of differentiated strategies (Bailey \& Williams-Black, 2008; Celedon-Pattichis, 2010; Cusumano \& Mueller, 2007; Dee, 2011; King-Shaver, 2008; Logan, 2011). Although there are several qualitative studies that validate differentiated instruction practices, research concerning the effects of differentiated instruction practices on students' achievement is lacking (Dee, 2011; Ernest, Thompson, Heckaman, Hull, \& Yates, 2011; McTigue \& Brown, 2005; National Center on Accessing the General Curriculum (NCAC), 2002).

In Lebanon, a new post-war curriculum was designed and implemented in 1997; the current Lebanese curriculum has been in place since then. Sab "Ayon (2012) reported, "the participants drew mostly on traditional methods with few instances of group activities, not all of which were successful or achieved the objective" (p. 117). One of the teaching methods that Sab'Ayon claimed to be followed was Cooperative Learning, henceforth CL. CL is an approach designed to manage students' group work. According to the participants in a study by (Sab 'Ayon 2012), it was difficult to be applied by teachers in public schools especially that they were asked to implement it after a short period of training.

Thus, disparity can be seen between the 1997 curriculum approach and the current educational trends mainly through the complete absence of any differentiated instruction approaches and the lack of efficiency of CL.

Differentiated instruction practices were developed to enhance the learning of students (Goodnough, 2010; Hayes \& Deyhle, 2001), but little is known about the relation between differentiation and the better achievement results and learning of students (Reis et al, 2011).

The purpose of this study is to examine the effect of incorporating differentiated instructional practices on students' achievement in the kindergarten classes.

Throughout this project the researcher will be looking for an answer to the following question:

Does incorporating differentiated instructional practices leads to significant increase in students' achievement in the kindergarten classes?

H1:

If differentiated instruction approach is incorporated in the kindergarten classroom, it will have a positive effect on the student's achievement.

$\mathrm{H} 0$ :

If differentiated instruction approach is incorporated in the kindergarten classroom, it will have no effect on the student's achievement.

\section{Literature Review}

This literature review presents a summary of the relevant literature and the research supporting differentiated instructional strategies and practices and provides the necessary information to understand what a differentiated instruction approach looks like in a classroom.

Differentiated instruction is a teaching approach based on the evidence that instructional approaches and strategies should vary and differ according to the different needs of the diverse learners in a classroom.

Thinking about differentiation started as a criticism to the "one size fits all" approach where two extremes of students, the high and the low, are not appropriately challenged and also as a refusal to the continuity of the technocratic and positivist tradition that was once supposed to be the mean to meet the society's needs. Technocratic and positivist tradition followed ineffective practices that produced citizens with high-test grades but without any real life skills and thinking abilities. Technocratic and positivist tradition was strongly criticized (M. Apple, 2003; Guba and Lincoln, 1989; Habermas, 1978; Giddens, 1976) and a change in the teaching routine was needed. Tomlinson suggests the theory of differentiation as a change in the teaching process by which it can meet the different needs of students and can help develop life-long learners. 


\section{Differentiated Instruction}

Literature regarding differentiated instruction includes several definitions of it. Roy et al. (2013) define differentiated instruction as "an approach by which teaching is varied and adapted to match the abilities of students using systematic procedures for academic progress monitoring and data-based decision-making" (p. 1187). Smit and Humpert (2012) define differentiated instruction as "an approach that enables teachers to plan strategically to meet the needs of every student" (p. 1153). Ruys, Defruyt, Rots \& Aelterman (2013) define differentiated instruction as "a set of strategies that will help teachers meet each student where they are when they enter class and move them forward as far as possible on their educational path" (p. 94). Tobin and Tippett (2014) define differentiated instruction as "an approach to teaching and planning that can address the needs of diverse learners in an inclusive classroom" (p. 1). Tomlinson, an expert in the field of differentiated instruction defines it the best way that fits this study and thus will be considered as a basis for this project. Tomlinson (2005) defines differentiated instruction as "a philosophy of teaching that is based on the premise that students learn best when their teachers accommodate the differences in their readiness levels, interests and learning profiles". Besides, differentiated instruction considers that all students are different; they learn differently and like different things (Anderson, 2007). Teachers who practice differentiated instruction are sensitive to the developmental differences among children (Salinger, 2006; Walpole, Justice, \& Invernizzi, 2004) and thus they plan, teach, and arrange the classroom environment in a way that accommodates each child's unique needs and interests.

\section{Differentiation: Interest, Readiness, and Learning Profiles}

Students are all different; they come to school from different backgrounds with different interests, knowledge and learning styles. Nordlund (2003) states, "teachers are clearly challenged by the task of diversifying instruction in order to help every child meet their full potential" (p. 1). When teachers consider and are aware of students' diverse interests, readiness levels, and learning profiles then they will provide better instruction and plan learning opportunities that promote student success.

Interests refer to "topics that motivate a student or peak one's curiosity" (Hall, 2009, p. 2). Allowing for student interests ensures that every single learner finds a place in the learning community (Lawrence-Brown, 2004).

Readiness is an "evaluation of the student's prior knowledge, understanding, and current skill level" (Hall, 2009, p. 2). Teachers should recognize the readiness levels of students and accommodate them by providing different levels of tasks (Tomlinson, 2001a, 2003).

Learning profiles are central in determining how lessons will be taught (Tomlinson 2000; Hall 2009). The learning profile of a student is the specialized style in which he-she prefers to learn (visually, auditory or kinesthetically).

Interest, readiness, and learning profiles match with content, process, and product when planning for a differentiated classroom.

\section{Differentiation: Content, Process, and Products}

Tomlinson (2001) stated "A differentiated classroom provides different avenues to acquiring content, to processing or making sense of ideas, and to developing products so that each student can learn effectively" (p. 1).

According to Tomlinson 2001, content is the "input" of teaching and learning. It is what is being taught or what teachers teach (p.72). Content can be differentiated by targeting specific goals for the student to master (Bailey \& Williams-Black, 2008).

Process is defined as "how the learners come to understand and assimilate facts, concepts, or skills" (Anderson, 2007, p. 50). Modifying the process requires variety of activities and teaching strategies for students to make sense of learning (Pham, H., 2012, p. 16). Effective activities help students to progress from a current point of understanding to a more complex level of understanding (Tomlinson, 2001, p. 79).

Product is the way students show what they have learned. Differentiating product is offering students varied opportunities to express what they know in various ways.

By differentiating instruction in these four ways, teachers are likely to find more ways for all students in a classroom to be engaged and motivated and will probably reach more students' valuable learning differences in a classroom.

\section{Related Studies}

Differentiated instruction is a debatable issue and it is a central topic in the research of several researchers. For the purposes of this study, only research studies dealing with differentiated instruction, over the last 11 years from 2005 to 2018, were included. Articles, journals, books and studies were included in this review if they made relevant reference to the model of differentiated instruction. Some of the studies reviewed are related to the importance of differentiated instruction, some are related to models inspired by differentiated instruction, others are related to the effect of 
differentiated instruction on students achievement while other studies presents a proof that the methods discussed in the theoretical framework used to differentiate instruction have/doesn't have a positive impact on students from different perspectives.

Strengthening the importance of differentiated instruction, Tomlinson \& McTighe (2006), Heacox (2012), Gregory \& Chapman (2012), and Tomlinson (2014) wrote guides and books that turn the theory of differentiated instruction into practice providing instructors with practical ways and strategies that help them differentiate.

Tomlinson \& McTighe's (2006) book “Integrating Differentiated Instruction \& Understanding by Design: Connecting Content and Kids" provides educators with two models that help meet a great challenge in teaching: producing powerful curriculum that ensures academic success for all learners. Besides, it shows them how to use the principles of both models to create lesson plans that teaches essential information and skills for variance learners. Authors consider that Understanding by Design is a curriculum design model that focuses on the need and what we teach. Differentiated Instruction is a framework for addressing learner variance that focuses on whom we teach, where we teach, and how we teach. Connecting content and kids in meaningful ways is what teachers strive to do every day.

In the updated edition of the guide "Differentiating Instruction in the Regular Classroom: How to Reach and Teach all Learners", Heacox (2012) provides a practical way for differentiation and explains how to differentiate instruction in order to provide variety in the ways teachers teach and students learn. Heacox explains some ways to get to know students and recognizes that all students have points of strengths and weaknesses; believing that not every gifted student is ready for higher-level thinking and not every student with learning differences is always incapable of moving to a higher level of thinking.

Gregory \& Chapman (2012) wrote "Differentiated Instructional Strategies: One Size Doesn't fit all" as a useful practical resource to meet the diverse needs of learners. The book show teachers what to do in the classroom by providing a comprehensive framework that describe all of the elements in a differentiated classroom including instructional best practices and curriculum models. Besides, teachers are provided with planning template that allows them to create lesson plans based on the common core state standards while differentiating at the same time based on students' readiness, interests and preferences.

Through her book "Differentiated Classroom: Responding to the Needs of all Learners", Tomlinson (2014) offers teachers a powerful and practical way to meet a very modern and completely timeless challenge: how to divide time, resources, and efforts to effectively instruct so many students of various backgrounds, readiness and skill levels, and interests. Tomlinson explains the theoretical framework of differentiated instruction, shares multiple instructional strategies, and then demonstrates how real teachers are applying differentiation strategies successfully in their classrooms responding to the needs of all learners. Tomlinson's book is considered as a good reference to tell what, how, and why to differentiate instruction in a classroom in a way that modifies the work of a teacher to be able to help every learner move toward maximized learning, more gained skills, and expanded understanding.

\section{Studies Related to the Effect of Differentiated Instruction on Students Achievement}

Koeze (2007) and Luster (2008) points out that differentiated instruction has a positive impact on students achievement. The focus of Koeze's study is to inspect the best teaching and learning practices that foster student learning. Through the use of quantitative and qualitative methods, data gathered were in support of the differentiation variables that had a positive relationship to student achievement. Choice, interest, learning styles, and pre-assessment were the most variables found to have impact on student achievement. Findings of the research support the theory of learning styles and the researcher suggests that teachers just beginning differentiation should first process a learning styles inventory to their students. Besides, the researcher provides teachers with two manageable techniques with which to begin differentiation: choice and interest.

Luster (2008) study whole-class and differentiated instruction to determine what is the most effective instructional strategy in an inclusive classroom. The book "A Quantitative Study Investigating the Effects of Whole-Class and Differentiated Instruction on Student Achievement" examines a research directed on elementary school mathematics education to investigate the academic impact of adapting instructional methods in a standards-based curriculum on students' abilities and learning styles. Math scores of 67 students receiving whole-class instruction are compared to math scores of 68 students receiving differentiated instruction. In addition, analysis of responses to a survey instrument assessing teacher attitudes regarding the value of the different forms of instruction reveal statistically significant differences between teachers' attitudes and so in student achievement levels. As a result, the study supports learner-centered classrooms to educate the diverse and heterogeneous population of students.

\section{Studies Related to Effectiveness of some Methods used to Differentiate Instruction}

The theoretical frame presented in this research includes some strategies that can be used to differentiate instruction through. Some related studies were found to prove or to deny the effect of some of the mentioned strategies and methods 
like learning styles, multiple intelligences, grouping, cooperative learning, and formative assessment.

Landrum \& McDuffie (2010) and Wilson (2011) found that there is no relation between students' academic achievement and students' learning styles. Unlike Least (2014) whose study proves that understanding students' learning styles and using them to differentiate will help students succeed. Landrum \& McDuffie's (2010) article aims to explore the concept of learning styles, and to discuss if styles are meaningful for educators teaching different learners. Since the research they did didn't support the learning styles as an important practice in teaching, Landrum \& McDuffie repel the temptation to try to match instructional methods to students' preferences. At the same time, they consider that differentiation provides one framework for individualizing in the context of a heterogeneous classroom.

Wilson (2011) examines the relationship between students' academic achievement levels and students' learning styles matched to the instructional strategies incorporated by their teachers. In the study, the researcher intended to analyze a sample of 200 elementary leveled students in thirteen general education classes from three schools in California. After analyzing the collected data, results show that there is a lack of strong possible relationship between the learning style preference of students in fourth grade and the instructional strategies of the teacher, and the academic achievement of those students as reflected in achievement test scores. Nevertheless, the results of the study provide important information concerning the field of learning styles and have valuable implications for educators.

Least's (2014) study shows that understanding student learning style may help students receive and process information more successfully. The case study investigates how two teachers worked together towards scaffolding differentiated instruction and how such instruction moved students along the continuum of learning. Many types of instructional strategies in the classroom were used to engage all students; differentiated instructional methods used during cooperative learning exercises have been shown in research to scaffold students learning. Results make it clear that differentiated instruction is a highly effective approach that teachers can no longer ignore.

Gangi (2011) and Murray \& Moore (2012) confirm that the multiple intelligences theory is an effective tool to differentiate instruction and reach all students. Gangi's (2011) study attempts to illustrate the usage of the multiple intelligences theory as an effective way to differentiate learning chances. Analysis of the literature review shows that (1) Gardner's multiple intelligences theory is an effective method to differentiate in the classroom where it allows teachers to explain a lesson in a variety of ways. (2) Using multiple intelligences leads to increase in their achievement levels since students' learning needs are closely matched. (3) No indications proved if the implementation of multiple intelligences in the school or classroom has an effect on the achievement gap between academic and cultural groups.

The study provided the teachers with recommendations that assist in making an informed decision whether or not to implement multiple intelligences as a differentiation method.

Murray \& Moore's (2012) findings explore how Gardner's multiple intelligences theory can be used in the classroom as a teaching tool to serve the needs of various types of learners. The authors conclude that in order to supply the different intelligences in a diverse classroom, teachers must differentiate the teaching-learning process. In order to create an inclusive classroom, the teacher, as explained, must differentiate the content, process and product to accommodate all learning styles. In the paper, it is noted that the application of Gardner's multiple intelligences theory helps to promote an inclusive environment by valuing that all individuals have strengths in different areas.

Adodo \& Agbayewa's (2011) study investigates the effect of homogeneous ability level grouping and heterogeneous ability class teaching on students' learning outcome. The study examines how to best give the low achievers in science the extra help they need without reducing the interest and progress of the high achievers. The sample included 60 students in the junior secondary school class; 30 randomly selected from 2 schools. Each of the schools served as experimental study for homogeneous and heterogeneous ability level grouping class respectively. The results show that homogeneous grouping is more effective for fostering students learning outcome and for boosting their interest to learning.

Tsay \& Brady (2012) note that cooperative learning has increasingly become a widespread form that reflects active education in academic organizations. The aim of the study they did is to explore the relationship between cooperative learning and academic performance in higher education.. Results from the study encourage the idea that cooperative learning is an active strategy that works on fostering higher academic levels of achievement.

Force (2013) considers that effective teachers are always engaged in the process of formative assessment. One reason for using formative assessment is that it can help in restructuring the curriculum to meet student needs and differentiating instruction among students. The research focuses on formative assessment as a series of action events that has a positive impact on instruction and students learning. The other parts of the research include a discussion of the other purposes of assessment, then a description of what formative assessment ought to be, emphasizing the vital importance of teacher decision making in the process of assessment. At the end, the author offers a checklist for decision makers that clarify the best ways to integrate formative assessment into the learning cycle of students. 


\section{Method}

This chapter contains a description of the (1) research design, (2) participants, (3) procedure, (4) instruments, (5) intervention, and (6) data analysis. The methodology of this research attempts to answer the research question: Does incorporating differentiated instructional practices leads to significant increase in students' achievement in the kindergarten classes?

\section{Design of the Study}

A quasi-experimental study design was used for this research because student classes were established prior to beginning the research study and random selection was not possible. Besides, this method provides the opportunity to collect, compare and analyze data on intact groups; a control group and an experimental group. The purpose of this action research was to examine the effect of incorporating differentiated instructional practices on students' achievement in the kindergarten classes where the differentiated instruction approach was considered as the independent variable and its effect on the student's achievement as the dependent variable. Action based research gave the researcher an idea of what to differentiate, how to group students, how to differentiate, how to collect data and assess students and then what and how to plan for more differentiated instructional practices based on the students' results. By using action research, the researcher, as the teacher, was able to see on the spot what parts of the intervention worked and which ones did not work and had to be modified. The researcher chose to differentiate the area of phonics skills according to students' readiness levels and considered some of the main aspects of differentiated instruction approach while differentiating activities for the whole group and for the small groups like: cooperative learning, learning styles, flexible groupings and tiered instruction.

\section{Participants}

Research was conducted over a three-weeks period at Al Ofoq Al Jadeed School in Saida - Lebanon. The study was conducted in two sections of kindergarten classrooms with typically developing students where one classroom with nineteen students formed the control group and the other classroom with also nineteen students formed the experimental group. Tackling the phonics skills, the control group received traditional teaching with no differentiated instruction, and the experimental group received differentiated instructional practices. The teacher of the control group did not receive any training or support on differentiation and did not change her teaching methods during the research time frame. On the other hand, the teacher of the experimental group did a research and learned about differentiated instruction from different aspects and modified her teaching methods and instructional practices in the light of content, process and product according to students' readiness levels. Both teachers teaching kindergarten classrooms at the time of the study and the thirty-eight students that formed both groups: control and experimental were identified as the sampling of the study. The researcher selected this population since the teacher of the control group taught the same kindergarten level (KG-3) as the researcher and planned for the same learning outcomes. Both teachers worked at the same school and could contact each other simply on daily basis. Moreover, students were of the same age group, which results in sharing some mutual characteristics, developmental milestones and in need for the $21^{\text {st }}$ century learning approaches that best fits their age group.

\section{Procedure}

The researcher wanted to change the way of teaching and learning in kindergarten and looked for the most modern approaches that were proven to meet the needs of all children. One of the approaches that caught the researcher's interest was the differentiated instruction approach. The researcher planned to learn about differentiated instruction by looking for information concerning the main aspects of the differentiation theory; how to translate differentiation theory into practice. The researcher learned how to design a differentiated plan and learned how to implement differentiation in daily teaching practices.

Before any practical planning, the researcher obtained approval from the school administrator, from the English department coordinator, and from the teacher of the other KG-3 section. Teacher of the control group was informed that there would be some times where she has to assess her students in coordination with the assessment of the experimental group and was provided with a recording sheet sample containing the names of her students to be used during assessment.

The action research of this study started with designing an instructional plan. McGraw-Hill Reading Wonders curriculum was used as the basis for all lesson plans that spanned a three-week period of classroom instruction. However, lessons were modified using cooperative learning, tiered instruction, vocabulary activities, games, and other components of differentiated instruction. All copies, worksheets, and materials were prepared at the beginning of the three-week research period.

The researcher picked the phonics skills to be differentiated since phonics forms the basis for reading instruction that 
teaches children the relationships between letters and sounds. The teacher decided to create lesson plans with differentiated content, process, and product depending on the readiness levels of the students.

To know the readiness level of each student at every new skill, the teacher prepared an entry card, implement it in the classroom, then analyzed the collected data using the analysis sheet and used the analyzed data to group students as below-level, on-level, and above-level. The teacher then planned differentiated instruction practices for every level regarding the content, process, and product. The teacher prepared activities, created worksheets, and designed some games that helped in achieving the learning outcomes for the three different levels of students in differentiated ways. The researcher requested from the kindergarten directress some materials that were needed. The requests were kindly supported and the materials were available in a short period of time. After the implementation of the differentiated practices, the teacher assessed her students and recorded the data collected on the designed recording sheet and planned to compare the results of the control group to the results of the experimental group over the three weeks of differentiation to check if the incorporation of the differentiated instruction approach in the kindergarten classroom had a positive effect on the student's achievement.

\section{Instruments}

To accumulate information for this study, many forms of data were collected. The data collected consists of entry cards, analysis sheets, and recording sheets.

Entry cards (Appendix A) were used periodically at the introduction time of every skill. The function of the entry cards existed in knowing the readiness level of every student. Each entry card consisted of three boxes; each reflected a specific achievement level; if students were able to do the work in the first box, they would move to the next, and if done again, students moved to finish the work in the third box. To know to which level did every student belong to, the teacher used the analysis sheet.

Analysis sheets (Appendix B) were also used to collect data for this study. The teacher used the analysis sheets to analyze the entry cards after being completed by students. The analysis sheets were designed by the teacher and consisted of student's names and the three levels of skills. The teacher put a tick beside the skill that a child was able to complete, counted the ticks below each skill, and classified students as below-level, on-level, or above-level. The teacher counted the number of students in every level and recorded it on the analysis sheet. The numbers guided the teacher when planning for the time of each activity for each student's level and when printing out worksheets.

Recording sheets (Appendix C) were utilized at the end of every learning outcome to assess the identified phonics skills. They consisted of student's names and the skills to be assessed. Both teachers of the control group and of the experimental group used a recording sheet in their classes to record data from students. Recording sheets of both groups were compared after the three-implementation weeks of differentiated practices to find out if they had an effect on students' achievement.

\section{Intervention}

The researcher chose to differentiate the content, process and product of the phonics skills area according to students' readiness levels. The teacher modified her daily teaching schedule to include 30 to 45 minutes of differentiated instruction for whole and small groups to be delivered by the regular classroom teacher 5 days per week. The teacher planned to implement the entry card on one day, work for three days with the whole group and with one of the three-leveled groups, and to assess all students in different ways on one day. The differentiated instructional plans were all designed and well studied ahead of the three intervention weeks. Materials were all prepared and organized on daily basis for the next intervention day.

In the classroom, the teacher worked individually with every student to complete the entry card and was taking notes about students' behaviors while completing each box. The notes helped the teacher later in grouping students. After grouping students, the teacher followed the implementation plan she already prepared for working with the whole group and with each small group for direct instruction. To help in producing organized planning for the three groups, the researcher used the tiering module (Appendix D) and followed the steps when planning for tiered activities. Tiered activities provided the opportunity for the students to focus on essential skills and understandings at different levels of complexity and helped the teacher in instructing the students according to deficits in specific skills.

When planning for learning experiences, the teacher used differentiated instruction strategies that include cooperative learning, flexible groups, learning styles and tiered activities. Differentiation even tackled the daily routines and practices of the kindergarten classroom since the researcher found that if added to the daily schedule, differentiated routines could have a positive impact on letter-sound fluency skill and thus on the recognition of each letter and its sound. After establishing the daily routines practices, the teacher started with the whole group activity that focused on the general learning outcome and then moved for working with the small group of the day. Since there was no assistant, 
the teacher prepared blocks, puzzle pieces, stories and other stuff for the whole group to work on and play with while working with the small group. The teacher asked the members of the small group to sit in one center to receive instruction as detailed below in the tables.

Teacher of the experimental group assessed her students in differentiated ways and recorded the results. At the same time the teacher of the control group was also assessing her students and recording results. The recording sheets were used at the end of three weeks intervention period to determine whether or not the interventions proved to be successful on effecting the achievement results of the experimental group compared to the achievement results of the control group.

The following tables present detailed information about the daily intervention practices that took place in the differentiated kindergarten classroom for three consecutive weeks.

\begin{tabular}{|c|c|c|}
\hline \multicolumn{3}{|c|}{ Week One: Differentiated Letter Nn } \\
\hline Day & Whole Group Activity & Small Group Activity \\
\hline 1 & $\begin{array}{c}\text { - Letter-sound fluency practice } \\
\text { - Nn rhyme to guess the /n/ sound } \\
\text { - Use accountable talk cards to tell who agrees or disagrees } \\
\text { it's the letter and why (Appendix E) } \\
\text { - Find Nn card for letter of the week focus wall } \\
\text { - Color Nn vocab on the alphabet chart (Appendix F) } \\
\text { - Fill and sing the letter Nn poster (Appendix G) }\end{array}$ & $\begin{array}{c}\text { Entry card to check the readiness level of every student } \\
\text { regarding letter } \mathrm{Nn}\end{array}$ \\
\hline 2 & $\begin{array}{l}\text { - Daily Routine: 1- Letter-sound fluency practice } \\
\text { 2- Letter Nn poster } \\
\text { - Use sticks to form letter Nn } \\
\text { - Circle all the Nn's } \\
\text { - Use clothespins to hang the letter cards on the Nn/not Nn } \\
\text { side of a clothesline }\end{array}$ & $\begin{array}{l}\text { Below level: cut, sort and paste the letters as } \mathrm{N} \text { or } \mathrm{n} \text { and not } \\
\qquad \mathrm{N} \text { or } \mathrm{n} \text { (Appendix } \mathrm{H})\end{array}$ \\
\hline 3 & $\begin{array}{c}\text { - Answer the yes/no question: do you have an Nn in your } \\
\text { name? } \\
\text { - Listen and dance to the letter Nn song } \\
\text { - Brainstorm letter Nn words } \\
\text { - Play the feed me game by sorting picture cards as start } \\
\text { with the N sound or not }\end{array}$ & $\begin{array}{c}\text { On level: cut, sort and paste the pictures as begin with the } \mathrm{N} \\
\text { sound or not (Appendix I) }\end{array}$ \\
\hline 4 & $\begin{array}{l}\text { - As cooperative groups, circle only the Nn's, draw as much } \\
\mathrm{Nn} \text { vocabs as members recall, and present the final work }\end{array}$ & $\begin{array}{c}\text { Above level: choose any card, check the picture on it, tell its } \\
\text { name, and find the bottle caps that have the letters of that } \\
\text { word. Build it up }\end{array}$ \\
\hline 5 & Assessment: letter name and sound & $\begin{array}{l}\text { - Below level: find } \mathrm{N} \text { and } \mathrm{n} \text { cards then use clothespins to } \\
\text { clip on } \mathrm{N} \text { and } \mathrm{n} \\
\text { - On level: make Nn snowman (uppercase, lowercase, and } \\
\text { matching picture) } \\
\text { - Above level: read and circle (Appendix J) }\end{array}$ \\
\hline \multicolumn{3}{|c|}{ Week Two: Differentiated Letter Cc } \\
\hline Day & Whole Group Activity & Small Group Activity \\
\hline 1 & $\begin{array}{c}\text { - Letter-sound fluency practice } \\
\text { - Cc rhyme to guess the /c/ sound } \\
\text { - Use accountable talk cards to tell who agrees or disagrees } \\
\text { it's the letter and why } \\
\text { - Find Cc card for letter of the week focus wall } \\
\text { - Color Cc vocab on the alphabet chart } \\
\text { - Fill and sing the letter Cc poster }\end{array}$ & $\begin{array}{c}\text { Entry card to check the readiness level of every student } \\
\text { regarding the letter } \mathrm{Cc}\end{array}$ \\
\hline 2 & $\begin{array}{c}\text { - Daily Routine: 1- Letter-sound fluency practice } \\
\text { 2- Letter Cc poster } \\
\text { - Circle all the Cc's on the morning message } \\
\text { - In the playground and as two big groups, race to sort the } \\
\text { letter cards into baskets as Cc and not Cc }\end{array}$ & $\begin{array}{c}\text { Below level: use straws to form letter Cc by tracing it on the } \\
\text { play dough }\end{array}$ \\
\hline 3 & $\begin{array}{l}\text { Answer the yes/no question: do you have a Cc in your } \\
\text { name? } \\
\text { - As music is on, play the snowball fight game by throwing } \\
\text { the crumpled papers on each other. When music is off, open } \\
\text { the paper, see the picture, check if it begins with } C \text { sound or } \\
\text { not and paste it on } C \text { paper or not } C \text { paper }\end{array}$ & $\begin{array}{l}\text { On level: color the pictures that begin with } \mathrm{C} \text { sound only to } \\
\text { make the letter } \mathrm{Cc} \text { bracelet (Appendix } \mathrm{K} \text { ) }\end{array}$ \\
\hline 4 & $\begin{array}{l}\text { - Listen and dance to the letter Cc song } \\
\text { - As groups, brainstorm Cc vocabs and draw them in the } \\
\text { outline display of the letter C provided for every group }\end{array}$ & $\begin{array}{l}\text { Above level: choose any picture card, tell its name, find the } \\
\text { letter cards that make up the word and build it up on word } \\
\text { builders }\end{array}$ \\
\hline 5 & Assessment: letter name and sound & $\begin{array}{l}\text { - Below level: scoop out the Cc's from the letter soup } \\
\text { - On level: use clothespins to clip on pictures that begin with }\end{array}$ \\
\hline
\end{tabular}




\begin{tabular}{|c|c|c|}
\hline & & $\begin{array}{c}\text { the c sound (Appendix L) } \\
\text { - Above level: read, cut and paste the matching picture to } \\
\text { the word (Appendix M) }\end{array}$ \\
\hline \multicolumn{3}{|c|}{ Week Three: Differentiated Letter Oo } \\
\hline Day & Whole Group Activity & Small Group Activity \\
\hline 1 & $\begin{array}{c}\text { - Letter-sound fluency practice } \\
\text { - Oo rhyme to guess the /o/ sound } \\
\text { - Use accountable talk cards to tell who agrees or disagrees } \\
\text { it's the letter and why } \\
\text { - Find Oo card for letter of the week focus wall } \\
\text { - Color Oo vocab on the alphabet chart } \\
\text { - Fill and sing the letter Oo poster }\end{array}$ & $\begin{array}{c}\text { Entry card to check the readiness level of every student } \\
\text { regarding the letter Oo }\end{array}$ \\
\hline 2 & $\begin{array}{l}\text { - Daily Routine: 1- Letter-sound fluency practice } \\
\text { 2- Letter Oo poster } \\
\text { - Circle all the Oo's on the morning message } \\
\text { - As groups, find all the Oo's on the big paper and paint } \\
\text { them using cotton buds }\end{array}$ & $\begin{array}{c}\text { Below level: complete the letter Oo maze by coloring the } \\
\text { Oo's only then find the letter Oo mat and form O and o } \\
\text { using play dough }\end{array}$ \\
\hline 3 & $\begin{array}{l}\text { Answer the yes/no question: do you have an Oo in your } \\
\text { name? } \\
\text { - Teacher says a word and learners raise up the happy face } \\
\text { card if the word starts with letter O or the sad face card if } \\
\text { not and correct }\end{array}$ & On level: create the letter Oo flip book (Appendix N) \\
\hline 4 & $\begin{array}{c}\text { - Listen and dance to the letter Oo song } \\
\text { - Dance to music, when paused the teacher calls on a name, } \\
\text { student checks the picture or the letter card that they get and } \\
\text { sort it as related to O or not }\end{array}$ & $\begin{array}{l}\text { Above level: read the word written on the cup to check if the } \\
\text { gem is below it }\end{array}$ \\
\hline 5 & Assessment: letter name and sound & $\begin{array}{l}\text { - Below level: roll the dice to find } O \text { and o } \\
\text { - On level: find the apple halves with } O \text { and o to have full } \\
\text { Oo apple and pick up an Oo picture } \\
\text { - Above level: read words and match to pictures (Appendix } \\
\text { O) }\end{array}$ \\
\hline & & \\
\hline
\end{tabular}

\section{Data Analysis}

Multiple sources of data collection were used in this study like entry cards, analysis sheets and recording sheets. The level of each student was clarified after analyzing the completed entry cards. The method of collecting assessment data of the identified phonics skills was a weekly data-recording sheet. At the end of every week and after working with each level according to its needs in the experimental group, teachers for both groups: control and experimental assessed their students' acquisition of the letter name taught over the week and its sound and recorded the results on the recording 
sheet. Thus, the researcher was able to compare the attainment of students of the experimental group that were taught by differentiated instruction with the attainment of students in the control group classroom which did not receive differentiated instruction. Data collected was analyzed using independent sample t-test to determine if a statistically significant difference was present between students' achievement means of the two group to determine if differentiated classrooms had better achievement results in the phonics skills area. The independent sample t-test allowed the researcher to test the hypothesis to determine whether or not the intervention caused a positive significant effect on the students' achievement.

\section{Conclusion}

This study used a quasi-experimental design to compare the assessment data over a three weeks period of kindergarteners instructed through using differentiated strategies and kindergarteners instructed using traditional teaching strategies. Independent sample t-test was conducted in this study to answer the research question: Does incorporating differentiated instructional practices leads to significant increase in students' achievement in the kindergarten classes?

\section{Results}

The purpose of this study was to examine the effect of incorporating differentiated instructional practices (independent variable) on students' achievement (dependent variable) in the kindergarten classes. Kindergarten sections were divided into two groups: a control group that received no differentiated instruction, and an experimental group that received differentiated instructional practices. The researcher differentiated instruction according to students' readiness levels and modified instruction by content, process, and product. The practices were incorporated for a period of three weeks. After that, the researcher collected the recording sheets that included assessment results of both the experimental group (Appendix P) and the control group (Appendix Q). The grading scale of the report card is interpreted as following: 5: Outstanding level of performance, 4: High level of performance, 3: Satisfactory level of performance, 2: Needs improvement in performance and 1: Unsatisfactory level of performance.

Data was analyzed using independent sample t-test to test the acceptation or rejection of the research hypotheses. H1: If differentiated instruction approach is incorporated in the kindergarten classroom, it will have a positive effect on the student's achievement. And H0: If differentiated instruction approach is incorporated in the kindergarten classroom, it will have no effect on the student's achievement. Using SPSS (Statistical Package for the Social Sciences), a t-test was conducted to determine if a significant difference existed between achievement results of both groups. The researcher studied the relation between the means of letters $\mathrm{Nn}, \mathrm{Cc}$ and Oo (names and sounds) of both groups in general to check if there is a significant difference between the results. Results are shown in table 1.

Table 1. t-test for the names and sounds of all the letters (Nn, Cc, and Oo)

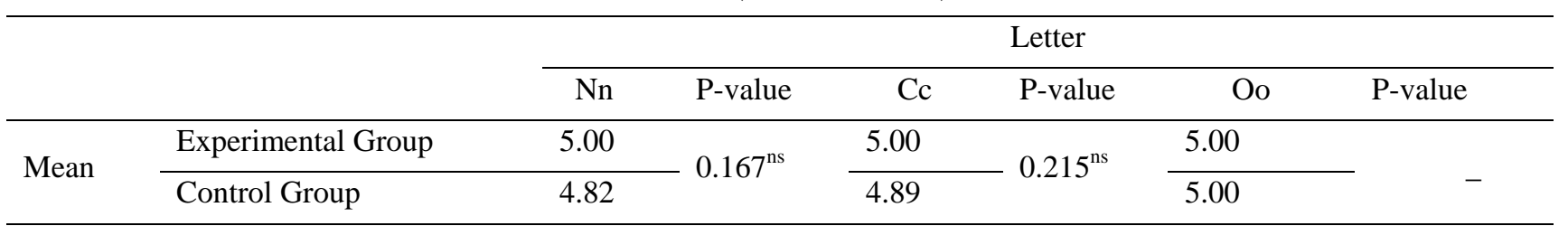

${ }^{n s}$ not significant

The researcher compared the mean (name and sound) of each letter of experimental group to that of the control group. The two p-values found were equal to .167 (letter Nn name and sound) and .215 (letter Cc name and sound); therefore, both p-values are greater than .05 and show that a significant difference between adjusted means does not exist. As for the letter Oo (name and sound), no p-value was found since achievement results were the same for both groups. Subsequently, these results failed to reject the null hypothesis. Thus, the researcher thought about studying the relation between the variables in a different way as shown in table 2.

Table 2. t-test for each competency of the letters $\mathrm{Nn}-\mathrm{Cc}-\mathrm{Oo}$

\begin{tabular}{|c|c|c|c|c|c|}
\hline & & \multicolumn{4}{|c|}{ Letters $\mathrm{Nn}-\mathrm{Cc}-\mathrm{Oo}$} \\
\hline & & Name & P-value & Sound & P-value \\
\hline \multirow{2}{*}{ Mean } & Experimental Group & 5.00 & \multirow{2}{*}{$0.163^{\mathrm{ns}}$} & 5.00 & \multirow{2}{*}{$0.135^{\mathrm{ns}}$} \\
\hline & Control Group & 4.89 & & 4.91 & \\
\hline
\end{tabular}

${ }^{n \text { not significant }}$

The mean of all name competencies was calculated for both groups, and then means were compared to each other (the 
same was done for all sound competencies). The p-values found were equal to .163 and .135 respectively; thus, $p$ (.163) and $p(.135)>.05$ show that no significant difference exists between adjusted means. Consequently, these results failed to reject the null hypothesis. So, the researcher compared the variables in a more specific way.

Table 3. t-test for each competency of letter Nn

\begin{tabular}{cccccc}
\hline & & \multicolumn{4}{c}{ Letter Nn } \\
\cline { 3 - 5 } & & Name & P-value & Sound & P-value \\
\hline \multirow{2}{*}{ Mean } & Experimental Group & 5.00 & \multirow{2}{*}{$0.163^{\text {ns }}$} & 5.00 & \multirow{2}{*}{$0.331^{\text {ns }}$} \\
\cline { 2 - 3 } & Control Group & 4.68 & & 4.95 & \\
\hline
\end{tabular}

${ }_{n \text { not significant }}$

Table 3 informs whether there was a statistically significant difference between experimental and control groups in achievement results of letter Nn name and letter Nn sound separately. The p-values found were equal to .163 and .331 respectively; then, $\mathrm{p}(.163)$ and $\mathrm{p}(.331)>.05$ show that there is no significant difference between the adjusted means.

Table 4. t-test for each competency of letter Cc

\begin{tabular}{llllll}
\hline & & \multicolumn{4}{c}{ Letter Cc } \\
\cline { 3 - 5 } & & Name & P-value & Sound & P-value \\
\hline \multirow{2}{*}{ Mean } & Experimental Group & 5.00 & & \multirow{2}{*}{$0.215^{\text {ns }}$} \\
\cline { 2 - 3 } & Control Group & 5.00 & - & 5.00 & 4.79 \\
\hline
\end{tabular}

$\overline{n s}$ not significant

Table 4 illustrates the difference between achievement results of letter $\mathrm{Cc}$ name and letter $\mathrm{Cc}$ sound of both groups separately. Results show that there was no p-value for the letter $\mathrm{Cc}$ name since the mean is the same for both experimental and control groups. However, the p-value of letter Cc sound was equal to .215 ; hence, $p(.215)>.05$ shows that a significant difference between adjusted means does not exist.

Table 5. t-test for each competency of letter Oo

\begin{tabular}{cccccc}
\hline & & \multicolumn{4}{c}{ Letter Oo } \\
\cline { 3 - 5 } & & Name & P-value & Sound & P-value \\
\hline \multirow{2}{*}{ Mean } & Experimental Group & 5.00 & & - & 5.00 \\
\cline { 2 - 5 } & Control Group & 5.00 & & 5.00 \\
\hline
\end{tabular}

Table 5 tells whether there was a statistically significant difference between experimental and control groups in achievement results of letter Oo name and letter Oo sound separately. No p-values were found for both competencies since achievement results of students in both groups were the same and resulted in equal means. This shows that a significant difference between adjusted means does not exist.

All results indicated that there were no significant differences in student achievement results between the differentiated and non-differentiated classrooms when compared to the .05 level. The null hypothesis was accepted as no significant achievement differences were found between the two groups. Furthermore, there is no significant effect for the incorporation of the differentiated instructional practices on the achievement results in the kindergarten classrooms.

\section{Discussion}

The results of the t-tests done for the analysis of achievement results of the experimental group and the control group revealed that an overall statistically significant difference did not exist. All statistical significance values ( $\mathrm{p}$-values) were more than .05 , which shows that there is no existence for a significant difference between adjusted means. Thus, these results accepted the null hypothesis:

H0: If differentiated instruction approach is incorporated in the kindergarten classroom, it will have no effect on the student's achievement.

An examination of these results shows that there is no positive effect on achievement results in kindergarten classrooms after the implementation of differentiated instructional practices. Although the effect size of the intervention is fairly small, these results were to some extent expected. The intervention for the implementation of differentiated teaching practices lasted only three weeks that is a short period of time for testing the effectiveness of a new teaching approach. During these weeks, an effective intervention could only make a limited difference to students' achievement. 
McAdamis (2001) supports the idea that the effect of differentiated teaching practices are not immediate, need time to make difference and may not be visible before some years of its implementation.

The results of this study, no significant change in achievement results after employing differentiated instructional practices, were different from the results of a study conducted by Koeze (2007) that aimed to inspect the best teaching and learning practices that foster student learning. Results were also different from another study conducted by Luster (2008) that aimed to determine the most effective instructional strategy in an inclusive classroom. Both studies conducted by Koeze and Luster revealed improved achievement results after incorporating differentiated instructional practices and proved it as an effective teaching approach. However, the results of this study were more in line with the results of an experimental study conducted by Wilson (2011) on 200 elementary leveled students in thirteen general education classes from three schools where the three schools showed no differences in achievement results.

\section{Recommendations}

This study did not show an effect of incorporating differentiated instructional practices on student achievement results in kindergarten classrooms, which may have been caused by several factors. This conclusion suggests various recommendations for future practice and research especially that the differentiation experience left a big influence on the researcher mainly after planning and implementing the intervention.

The researcher recommends for other teachers willing to incorporate differentiated instructional practices to start differentiating in the most accessible way in their own classrooms and to take small steps toward implementation. Teachers can start with one student or one activity and then proceed by differentiating content, process, or product. One important thing for teachers to do is to adjust their schedule to include time for differentiation and then plan, collect, bring in, and utilize as many purposeful resources as possible. Incorporating different activities with different challenges and expectations (Wehrmann, 2000) and varying the instructional methods used throughout each single lesson will let students feel motivated and excited for not doing more or less of the same thing repetitively. The researcher suggests that teachers take into consideration the students' multiple intelligences, learning styles, interest, readiness, and learning profiles. This will spontaneously vary activities and thus meet the needs of all students. To make a change, teachers must understand that differentiated instruction is not only a teaching strategy, but also an attitude toward helping all students achieve success. Change is not easy; change requires time, patience, and practice. Most teachers already use strategies in their classrooms that can be tailored to maximize student learning like technology, visual aids, effective learning experiences and hands-on activities.

The researcher suggests that further research should focus on how teachers actually understand and respond to diversity in the classroom. Research on the thoughts of teachers regarding differentiated instruction is needed. Through such research it is possible to ask teachers whether they think it is difficult to differentiate and why. After finding thoughts, it will be feasible to determine why teachers do not make decisions regarding differentiation in their classroom; this may be useful in removing the obstacles the teachers face in providing differentiated instruction. Of course, there is still a long way for research in order to determine through extended studies the effectiveness of differentiation through time, for all students, in different educational levels (primary, elementary, secondary) and across subjects.

\section{Conclusion}

Teachers are holding the responsibility of providing the most effective instructional methods to students. Recognizing that differentiated instruction does not affect students' achievement results may challenge some of the current insights of classroom instruction. Many studies examined the need for modified instruction and implementation strategies. However, research is limited validating or nullifying the impact of differentiated instruction on achievement results, which explains the need for extra inquiry in this domain. In summary, new obstacles will pop out in education on a continuing basis. Finding effective ways of creating 21st century learners, capable of excelling globally, must be the motivating force of today's educational system.

\section{References}

Adodo, S. O., \& Agbayewa, J. O. (2011). Effect of Homogenous and Heterogeneous ability grouping class teaching on students interest, attitude and achievement in Integrated science. International Journal of Psychology and Counselling, 3(3), 48-54.

Anderson, K. (2007). Tips for teaching: Differentiating instruction to include all students. Preventing School Failure, 3(51), 49-54. https://doi.org/10.3200/PSFL.51.3.49-54

Apple, Michael W. et al. (2003). The State and the Politics of Knowledge. New York:Routledge Falmer. https://doi.org/10.4324/9780203441190

Bailey, J. P., \& Williams-Black, T. H. (2008). Differentiated instruction: Three teachers ${ }^{\text {ee }}$ perspectives. College Reading 
Association Yearbook, 29, 133-151.

Beecher, M., \& Sweeny, S. M. (2008). Closing the achievement gap with curriculum enrichment and differentiation: One school "es story. Journal of Advanced Academics, 19(3), 502-530. https://doi.org/10.4219/jaa-2008-815

Brimfield, R., Masci, F., \& DeFiore, D. (2002). Differentiating instruction to teach all learners. Middle School Journal, 33(3), 1-5. https://doi.org/10.1080/00940771.2002.11494669

Brooks-Gunn, J., \& Duncan, G. J. (1997). The effects of poverty on children. In R. Behrman (Ed.), The Future of Children: Children and Poverty, 7, 55-71. https://doi.org/10.2307/1602387

Celedon-Pattichis, S. (2010). Implementing reform curriculum: Voicing the experiencesof an ESL/mathematics teacher. Middle Grades Research Journal, 5(4), 185-198.

Cusumano, C., \& Mueller, J. (2007). How differentiated instruction helps struggling students. Leadership, 8-10.

Cusumano, C., \& Mueller, J. (2007). How differentiated instruction helps struggling students: This school's reorganization to support differentiated instruction has resulted in a remarkable improvement in student performance levels. (Holland Elementary School). Leadership, 36(4), 8.

De Civita, M., Pagani, L., Vitaro, F., \& Tremblay, R. E. (2004). The role of maternal educational aspirations in mediating the risk of income source on academic failure in children from persistently poor families. Children and Youth Services Review, 26, 749-769. https://doi.org/10.1016/j.childyouth.2004.02.019

Dee, A. L. (2011). Preservice teacher application of differentiated instruction. The Teacher Educator, 46, 53-70. https://doi.org/10.1080/08878730.2010.529987

Ernest, J. M., Thompson, S. E., Heckaman, K. A., Hull, K., \& Yates, J. (2011). Effects and social validity of differentiated instruction on student outcomes for special educators. Journal of the International Association of Special Education, 12(1), 33-41.

Fisher, D., Frey, N., \& Williams, D. (2003). It takes us all. Principal Leadership, 4(3), 41-44.

Force, N. A. T. (2013). Formative assessment that truly informs instruction. Urbana, IL: National Council of Teachers of English.

Fryer, R. G., Jr., \& Levitt, S. D. (2004). Understanding the Black-White test score gap in the first two years of school. Review of Economics and Statistics, 86, 447-464. https://doi.org/10.1162/003465304323031049

Fryer, R. G., Jr., \& Levitt, S. D. (2006). The Black-White test score gap through third grade. American Law and Economics Review, 8. https://doi.org/10.3386/w11049

Gangi, S. (2011). Differentiating Instruction using Multiple Intelligences in the Elementary School Classroom: A Literature Review (Doctoral dissertation, University of Wisconsin--Stout).

Giddens, A. (1976). New Rules of Sociological Method, Basic Books:Hutchinson/New York.

Goodnough, K. (2010). Investigating Pre-service Science Teachers' Developing Professional Knowledge Through the Lens of Differentiated Instruction. Research Science Education, 40, 239-265. https://doi.org/10.1007/s11165-009-9120-6

Gregory, G. H., \& Chapman, C. (2012). Differentiated instructional strategies: One size doesn't fit all. Corwin Press.

Guba, E., \& Lincoln, Y. (1989). Fourth Generation Evaluation, Newbury Park: Sage

Habermas, J. (1978). Knowledge and Human Interests, translated by Jeremy Shapiro, $2^{\text {nd }}$ edition, London:Heinemann.

Hall, B. (2009). Differentiated instruction: Reaching all students. Research Into PracticeMathematics, Pearson, 1-5.

Hayes, M. T., \& Deyhle, D. (2001). Constructing Difference: A Comparative Study of Elementary Science Curriculum Differentiation. John Wiley \& Sons, Inc., 239-262. https://doi.org/10.1002/sce.1008

Heacox, D. (2012). Differentiating instruction in the regular classroom: How to reach and teach all learners (Updated anniversary edition). Free Spirit Publishing.

King-Shaver, B. (2008). Differentiated instruction: The new and not so new. California English, 13(4), 6-8.

Koeze, P. A. (2007). Differentiated instruction: The effect on student achievement in an elementary school.

Koutselini, M. (2006). Towards a meta-modern paradigm of curriculum: Transcendence of a mistaken reliance on theory. Educational Practice and Theory, 28(1), 55-69. https://doi.org/10.7459/ept/28.1.05

Landrum, T. J., \& McDuffie, K. A. (2010). Learning styles in the age of differentiated instruction. Exceptionality, 18(1), 6-17. https://doi.org/10.1080/09362830903462441 
Lawrence-Brown, D. (2004). Differentiated instruction: Inclusive strategies for standards based learning that benefit the whole class. American Secondary Education, 32(3), 34-62.

Least, S. K. (2014). Differentiated Instruction: Its effect on proximal development.

Lewis, S., \& Batts, K. (2005). How to implement differentiated instruction? Adjust, adjust, adjust. Journal of Staff Development, 26(4), 26-31.

Logan, B. (2011). Examining differentiated instruction: Teachers respond. Research in Higher Education Journal, 13, $1-14$.

Luster, R. J. (2008). A quantitative study investigating the effects of whole-class and differentiated instruction on student achievement. ProQuest.

Mastropieri, M. A., Scruggs, T. E., Norland, J. J., Berkeley, S., McDuffie, K., Tornquist, E. H., \& Connors, N. (2006). Differentiated curriculum enhancement in inclusive middle school science: Effect on classroom and high-stakes tests. The Journal of Special Education, 40(3), 130-137. https://doi.org/10.1177/00224669060400030101

McAdamis, S. (2001). Teachers tailor their instruction to meet a variety of student needs. Journal of Staff Development, 22(2), 1-5.

McTighe, J., \& Brown, J. L. (2005). Differentiated instruction and educational standards:Is détente possible? Theory Into Practice, 44(3), 234-244. https://doi.org/10.1207/s15430421tip4403_8

Murray, S., \& Moore, K. (2012). Inclusion through multiple intelligences. Journal of Student Engagement: Education Matters, 2(1), 42-48.

National Center on Accessing the General Curriculum. (2002). Differentiated instruction. Retrieved from http://www.cast.org/system/galleries/download/ncac/DifInstruc.pdf

Nordlund, M. (2003). Differentiated instruction: Meeting the educational needs of all students in your classroom. Maryland, Scarecrow Press.

Nugent, L. (2006). When technology met accountability. T H E Journal, 33(12), 41. https://doi.org/10.1176/pn.41.11.0033

Pham, H. (2012). Differentiated instruction and the need to integrate teaching andpractice. Journal of College Teaching \& Learning, 9(1), 13-20. https://doi.org/10.19030/tlc.v9i1.6710

Reis, S. M., McCoach, D. B., Little, C. A., Muller, L. M., \& Kaniskan, R. B. (2011). The Effects of Differentiated Instruction and Enrichment Pedagogy on Reading Achievement in Five Elementary Schools. American Educational Research Journal, 48(20), 462-501. https://doi.org/10.3102/0002831210382891

Rock, M. L., Gregg, M., Ellis, E., \& Gable, R. A. (2008). REACH: A framework for differentiating classroom instruction. Preventing School Failure: Alternative Education for Children and Youth, 52(2), 31-47. https://doi.org/10.3200/PSFL.52.2.31-47

Roy, A., Guay, F., \& Valois, P. (2013). Teaching to address diverse learning needs: development and validation of a Differentiated Instruction Scale, International Journal of Inclusive Education, 17(11), 1186-1204. https://doi.org/10.1080/13603116.2012.743604

Ruys, I., Defruyt, S., Rots, I., \& Aelterman, A. (2013). Differentiated instruction in teacher education: A case study of congruent teaching, Teachers and Teaching: theory and practice, 19(1), 93-107. https://doi.org/10.1080/13540602.2013.744201

Saba 'Ayon, N. (2012). Lebanese English as a foreign language teachers' conceptions of teaching and their practice in Lebanese public high schools. DPhil Thesis, University of Sussex.

Salinger, T. (2006). Policy decisions in early literacy assessment. In D. Dickinson \& S. Neuman (Eds.), Handbook of early literacy research (pp. 427-444). New York: Guilford Press.

Smit, R., \& Humpert, W. (2012). Differentiated instruction in small schools. Teaching and Teacher Education, 28, 1152 -1162. https://doi.org/10.1016/j.tate.2012.07.003

Strand, S. (1999). Ethnic group, sex and economic disadvantage: Associations with pupils' educational progress from Baseline to the end of Key Stage 1. British Educational Research Journal, 25, 179-202. https://doi.org/10.1080/0141192990250204

Tieso, C. (2001). Curriculum: Broad brushstrokes or paint-by-the-numbers? The Teacher Educator, 36(3), 199-213.

Tobin, R., \& Tippett, C. D. (2014). Possibilities and potential barriers: Learning to plan for differentiated instruction in 
elementary science. International Journal of Science and Mathematics Education, 12(2), 423-443. https://doi.org/10.1007/s10763-013-9414-z

Tomlinson, C. (1999). The Differentiated Classroom: Responding to the Needs of All Learners. Alexandria, VA: Association for Supervision and Curriculum Development.

Tomlinson, C. (2000). Differentiation of instruction in the elementary grades. Champaign, IL: ERIC Clearinghouse on Elementary and Early Childhood Education. (ERIC Document Reproduction Service No. ED443572).

Tomlinson, C. (2001). Hovtl to differentiate instruction in mixed-ability classrooms. Alexandria, V A. Association for Supervision and Curriculum Development.

Tomlinson, C. A. (2001). How to differentiate instruction in mixed-ability classrooms, (2 ${ }^{\text {nd }}$ ed). Alexandria, VA: Association for Supervision and Curriculum Development.

Tomlinson, C. A. (2001a). Differentiated instruction in the regular classroom. Understanding Our Gifted, 14(1), 3-6.

Tomlinson, C. A. (2003). Deciding to teach them all. Educational Leadership, 61(2), 6-11.

Tomlinson, C. A. (2005). Grading and differentiation: Paradox or good practice? Theory into Practice, 44(3), 262-269. https://doi.org/10.1207/s15430421tip4403_11

Tomlinson, C. A. (2014). Differentiated classroom: Responding to the needs of all learners. Ascd.

Tomlinson, C. A., \& Eidson, C. C. (2003). Differentiation in practice: A resource guide for differentiating curriculum. Alexandria, VA: Association for Supervision and Curriculum Development, 249-281.

Tomlinson, C. A., \& McTighe, J. (2006). Integrating differentiated instruction \& understanding by design: Connecting content and kids. ASCD.

Tsay, M., \& Brady, M. (2012). A case study of cooperative learning and communication pedagogy: Does working in teams make a difference? Journal of the Scholarship of Teaching and Learning, 10(2), 78-89.

Valiande, S. (2010). Differentiated Teaching in Mixed Ability Classrooms / Learning Processes and Effectiveness. Unpublished doctoral dissertation, University of Cyprus, Nicosia, CY. (In Greek). ISBN 978-9963-689-91-0

Walker, S. Y. (2002). The survival guide for parents of gifted kids. Minneapolis, MN: Free Spirit Publishing Inc.

Walpole, S., Justice, L., \& Invernizzi, M. (2004). Closing the gap between research and practice: Case study of school-wide literacy reform. Reading \& Writing Quarterly, 20(3), 261-283. https://doi.org/10.1080/10573560490429078

Wehrmann, K. S. (2000). How to differentiate instruction: Baby steps: A beginner"s guide. Educational Leadership, 58(1), 20-23.

Wilson, M. L. (2011). Students' Learning Style Preferences and Teachers' Instructional Strategies: Correlations Between Matched Styles and Academic Achievement (Doctoral dissertation, Liberty University). 


\section{Appendices}

Appendix A

Entry Card Sample

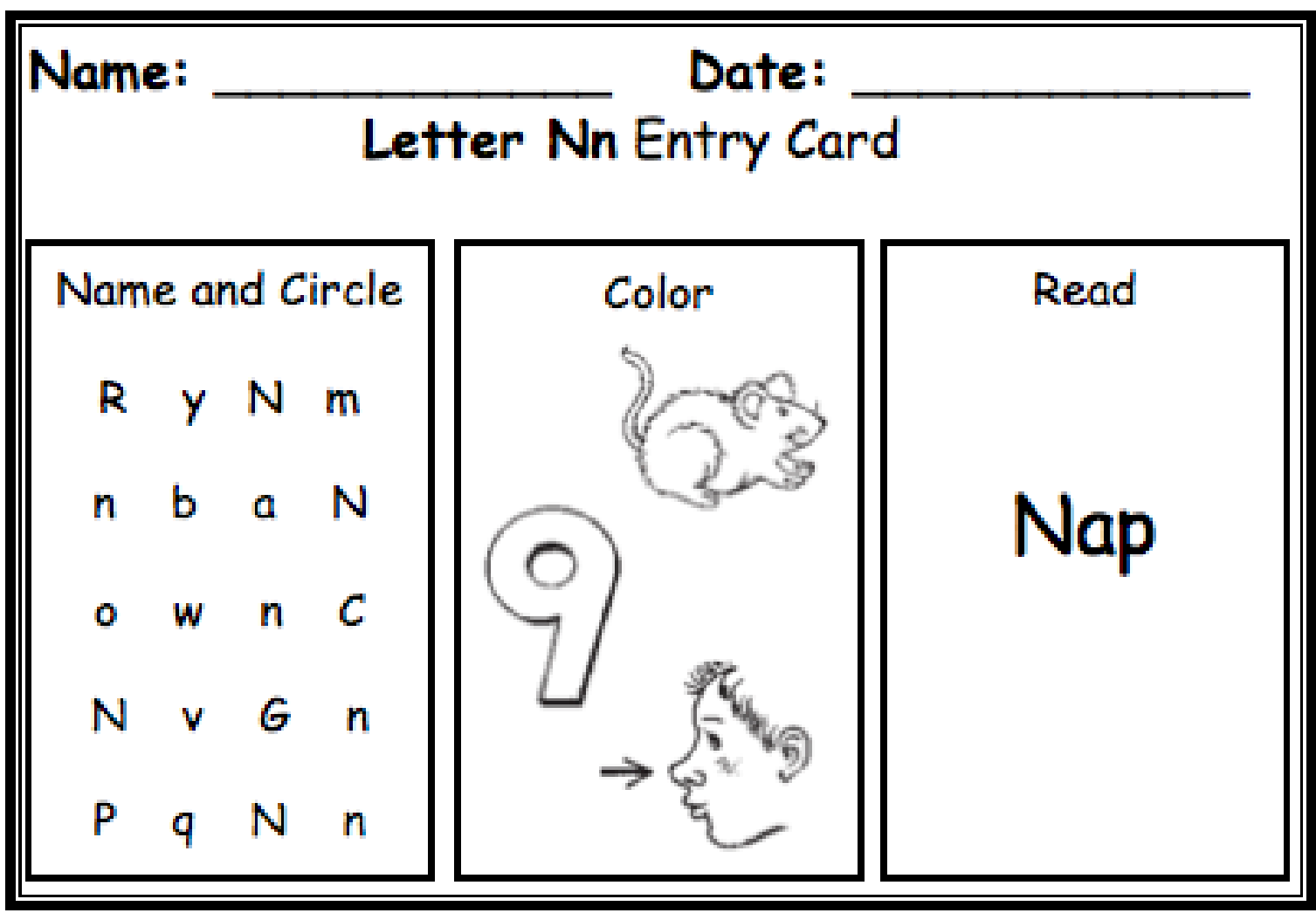


Appendix B

Analysis Sheet Sample

\section{Analysis of Letter Nn Entry Card}

\begin{tabular}{|c|l|l|l|l|}
\hline \multicolumn{2}{|c|}{ Student Name } & Name & Sound & Blend \\
\hline 1 & & & & \\
\hline 2 & & & & \\
\hline 3 & & & & \\
\hline 4 & & & & \\
\hline 5 & & & & \\
\hline 6 & & & & \\
\hline 7 & & & & \\
\hline 8 & & & & \\
\hline 9 & & & & \\
\hline 10 & & & & \\
\hline 11 & & & & \\
\hline 12 & & & & \\
\hline 13 & & & & \\
\hline 14 & & & & \\
\hline 15 & & & & \\
\hline 16 & & & & \\
\hline 17 & & & & \\
\hline 18 & & & & \\
\hline 19 & & & & \\
\hline 8 Below-level: & & & & \\
\hline & & & & \\
\hline
\end{tabular}


Appendix C

Recording Sheet Sample

Name-Sound Recording sheet

\begin{tabular}{|c|c|c|c|c|c|c|c|}
\hline \multirow{2}{*}{\multicolumn{2}{|c|}{ Student Name }} & \multicolumn{2}{|c|}{ Letter Nn } & \multicolumn{2}{|c|}{ Letter $C c$} & \multicolumn{2}{|c|}{ Letter Oo } \\
\hline & & Name & Sound & Name & Sound & Name & Sound \\
\hline 1 & & & & & & & \\
\hline 2 & & & & & & & \\
\hline 3 & & & & & & & \\
\hline 4 & & & & & & & \\
\hline 5 & & & & & & & \\
\hline 6 & & & & & & & \\
\hline 7 & & & & & & & \\
\hline 8 & & & & & & & \\
\hline 9 & & & & & & & \\
\hline 10 & & & & & & & \\
\hline 11 & & & & & & & \\
\hline 12 & & & & & & & \\
\hline 13 & & & & & & & \\
\hline 14 & & & & & & & \\
\hline 15 & & & & & & & \\
\hline 16 & & & & & & & \\
\hline 17 & & & & & & & \\
\hline 18 & & & & & & & \\
\hline 19 & & & & & & & \\
\hline
\end{tabular}


Appendix D

Tiering Module

\section{Tiered Activity Planning Template}
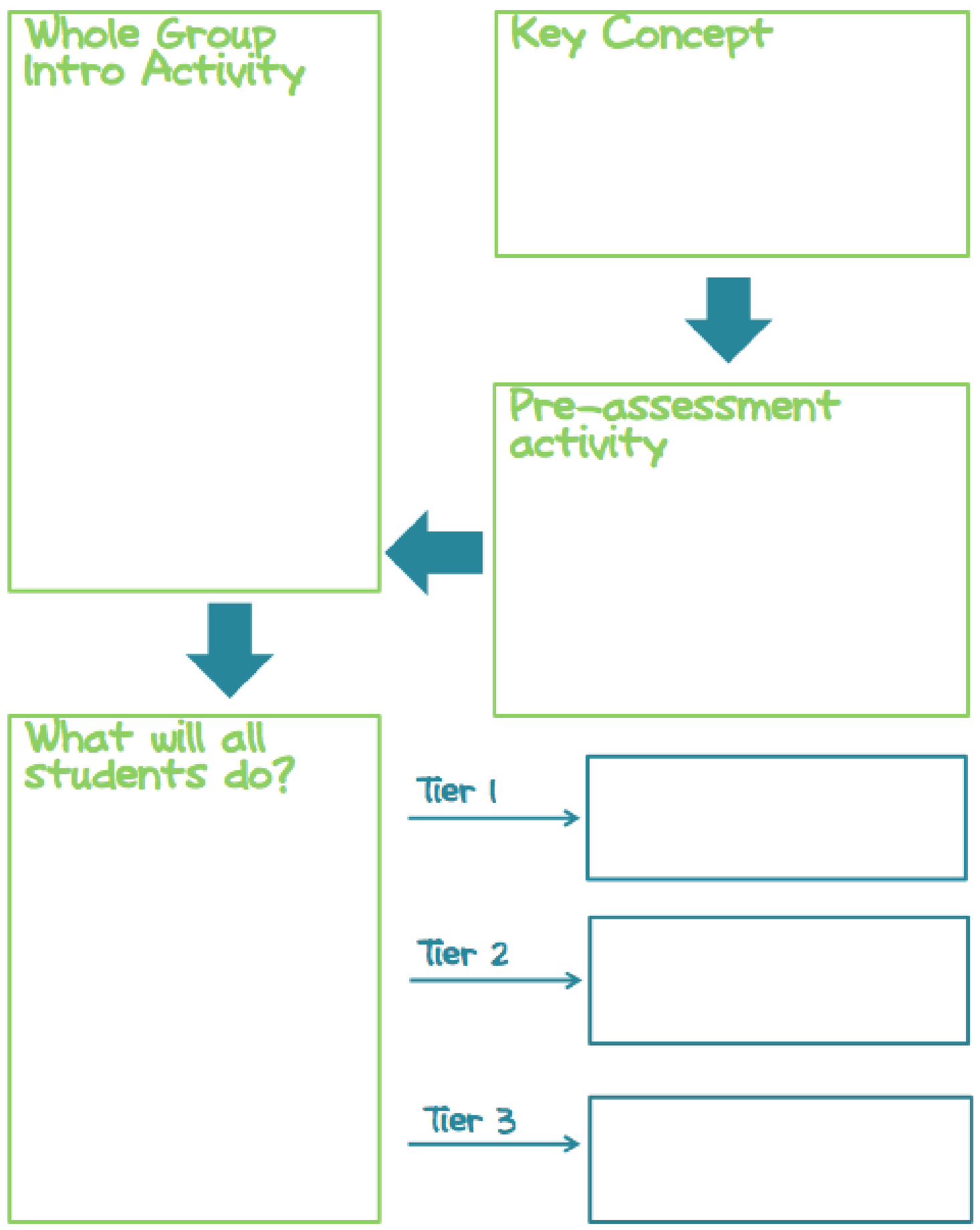
Appendix E

Accountable Talk Cards

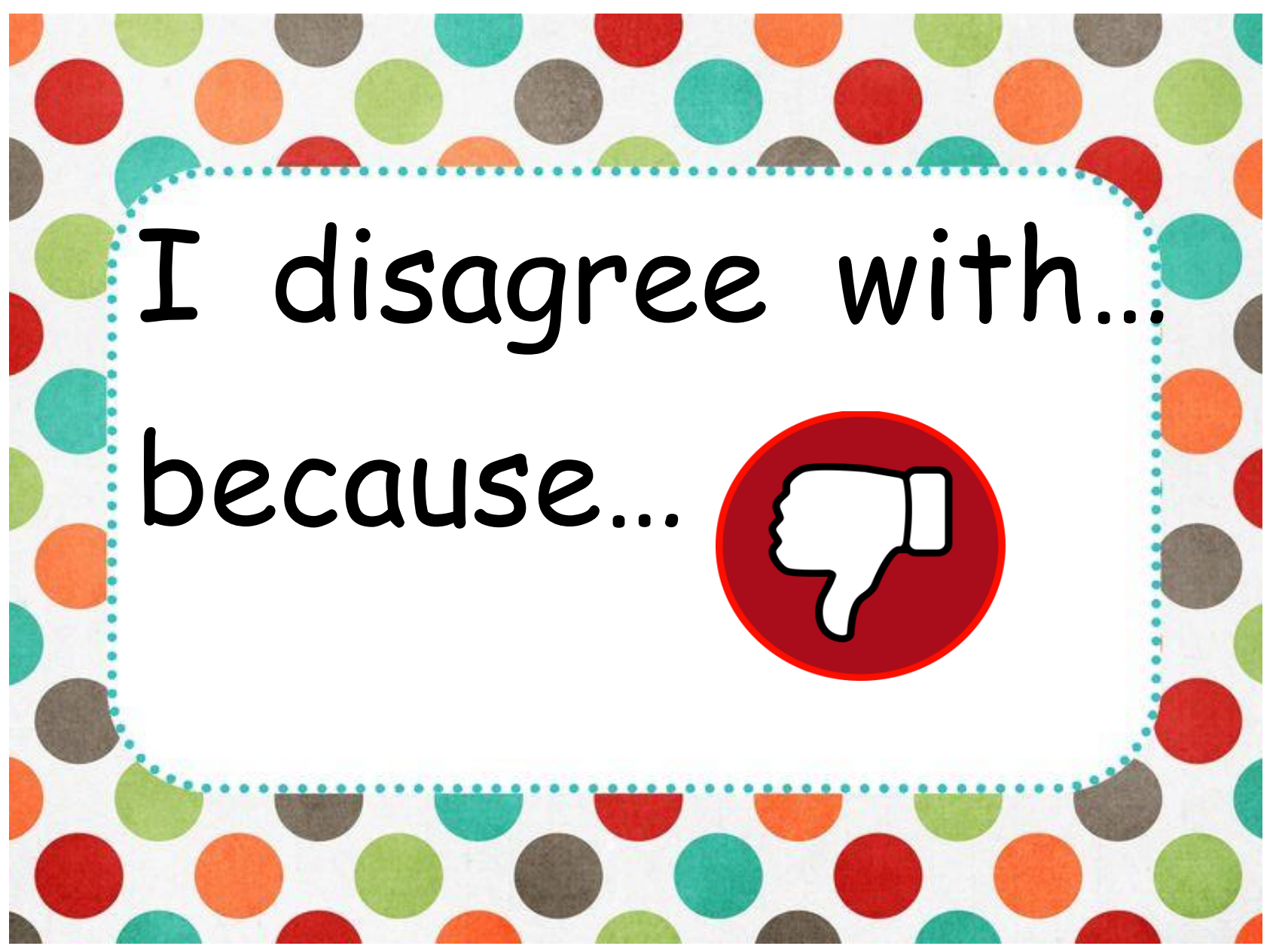




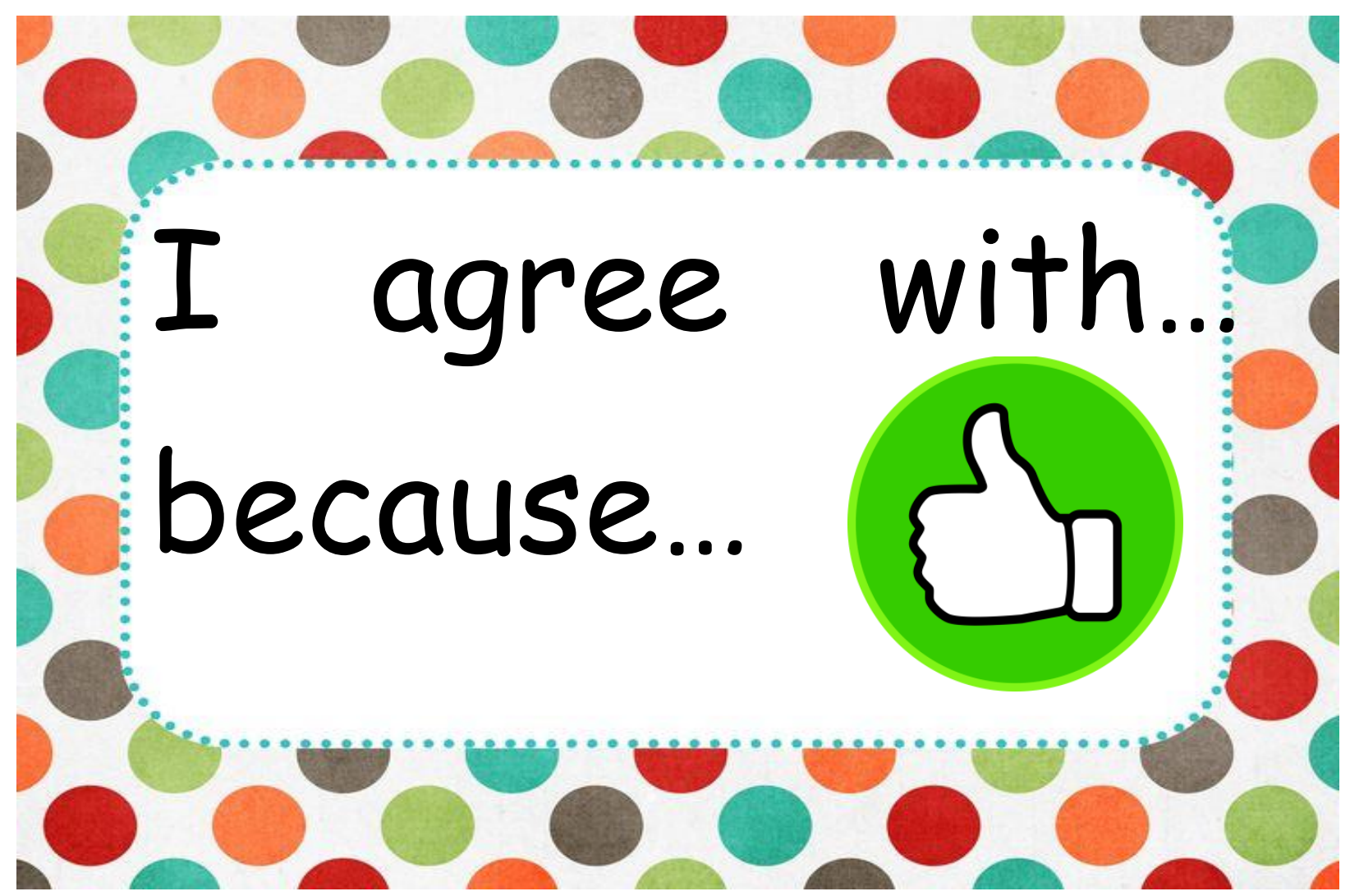


Appendix F

Alphabet Chart

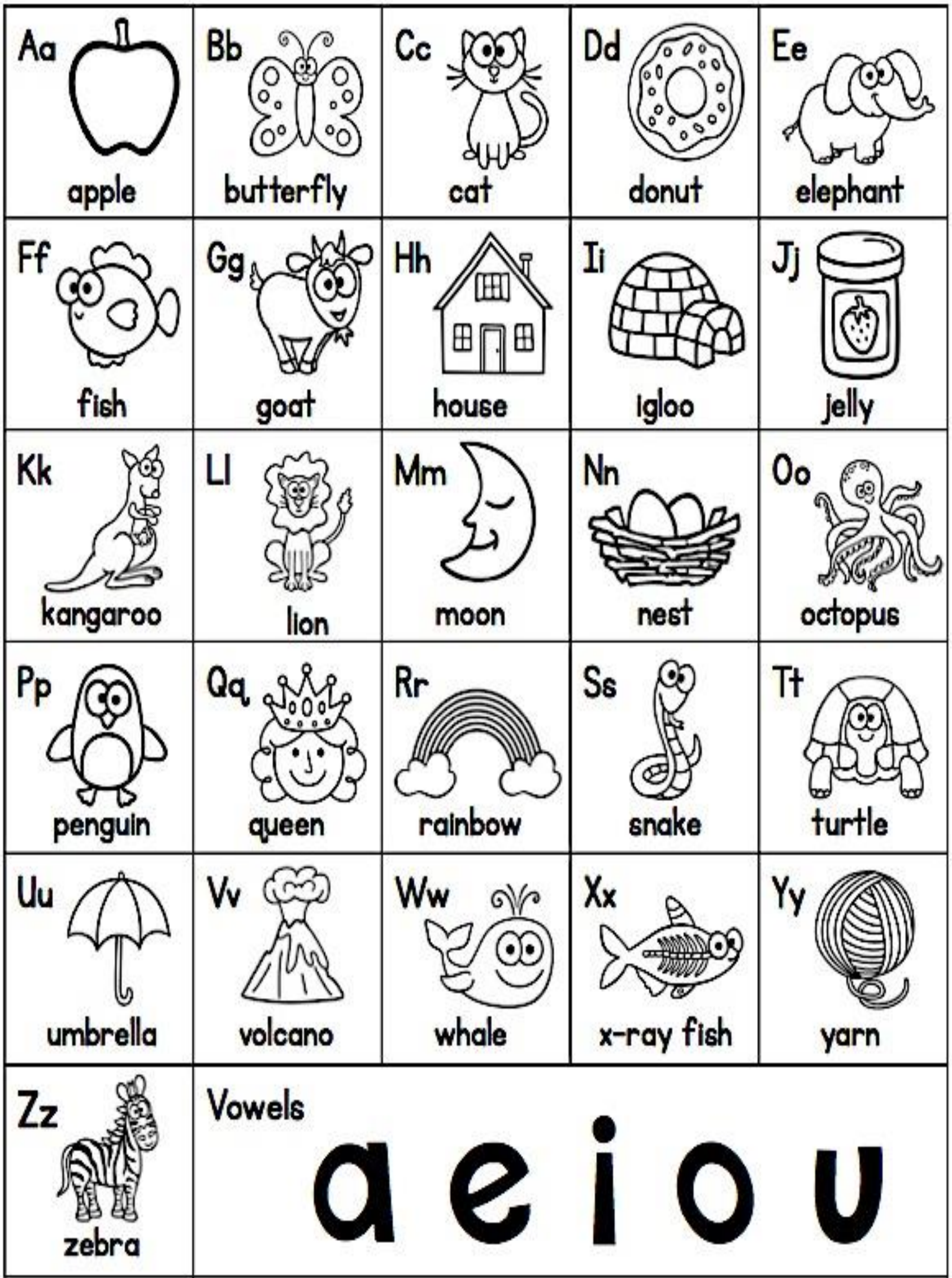


International Journal of Contemporary Education

Vol. 2, No. 2; October 2019

Appendix G

Letter Poster Sample
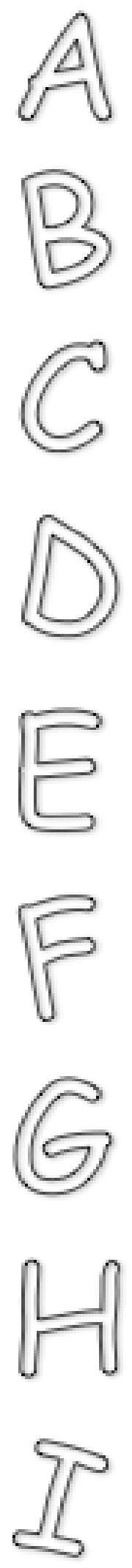

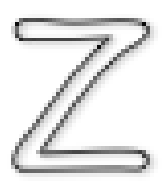

There is a letter

that we know, and is its name-o.
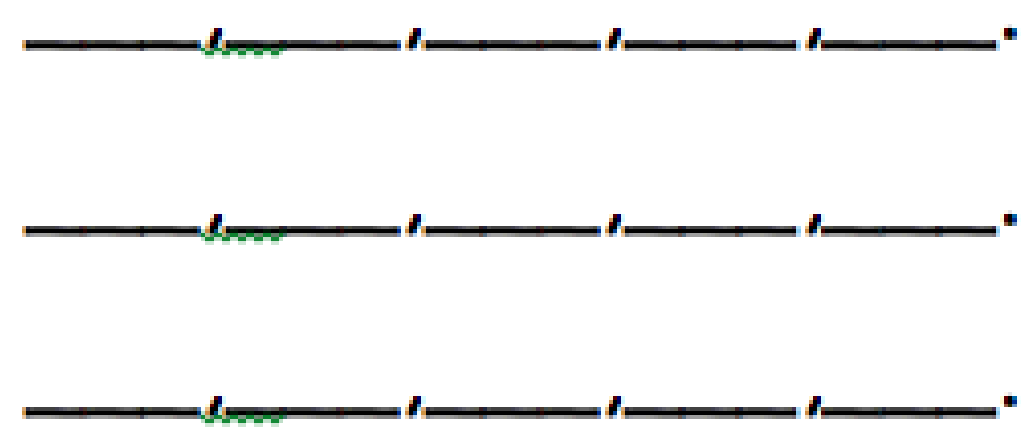

And

name-o

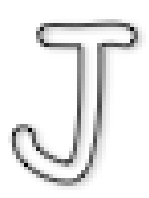

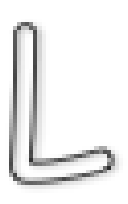

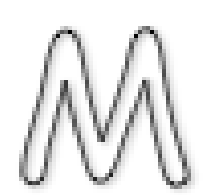

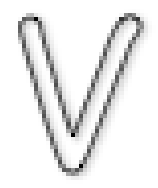
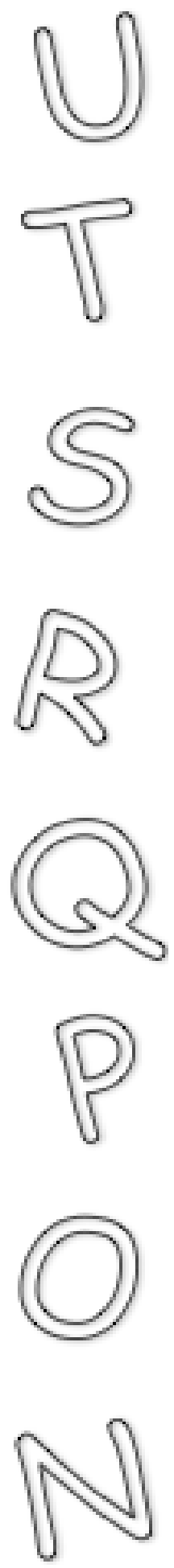

83 
Appendix $\mathbf{H}$

Letter Nn: Cut and Sort

Name:

\section{Sort the letters}

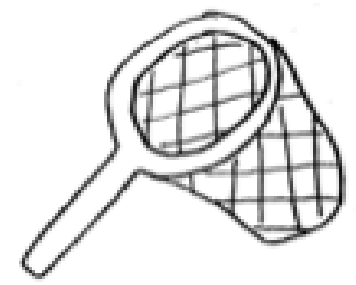

Nor $n$

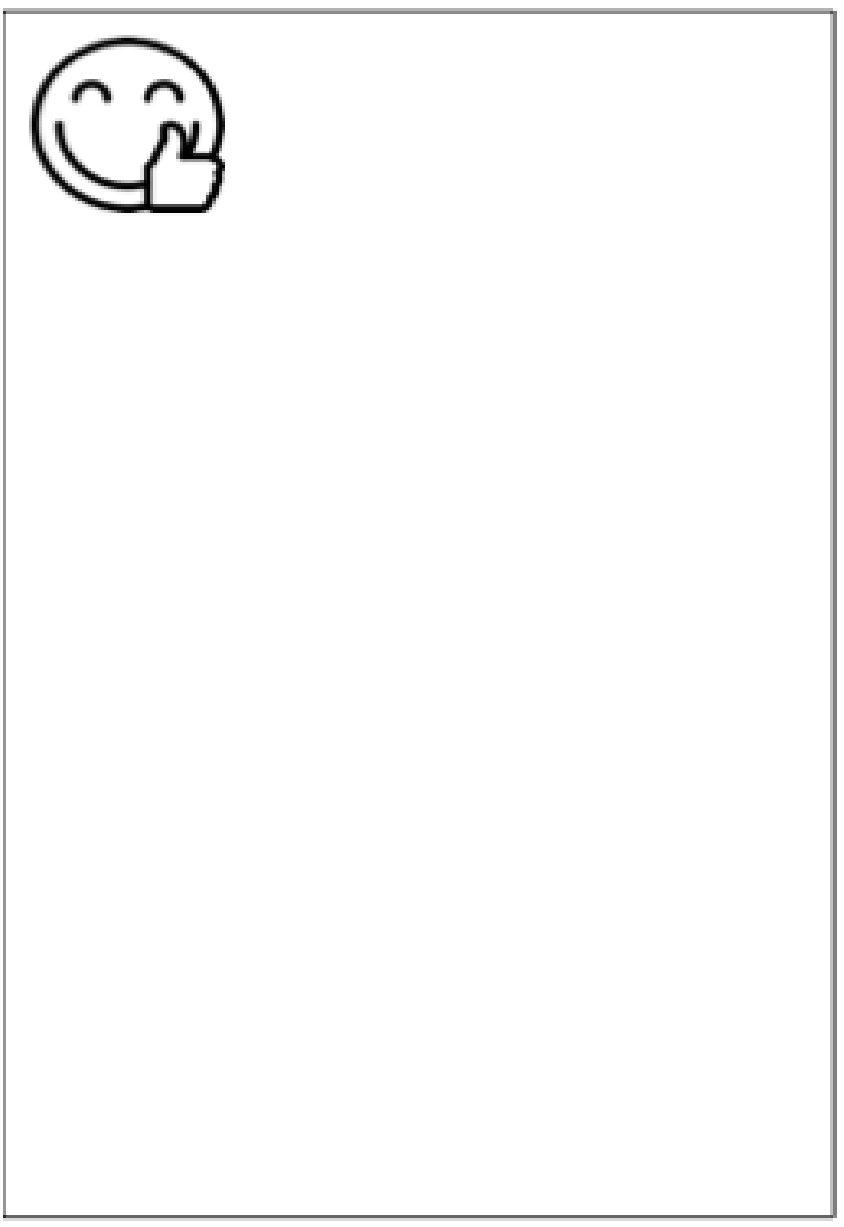

Not $\mathrm{N}$ or $n$

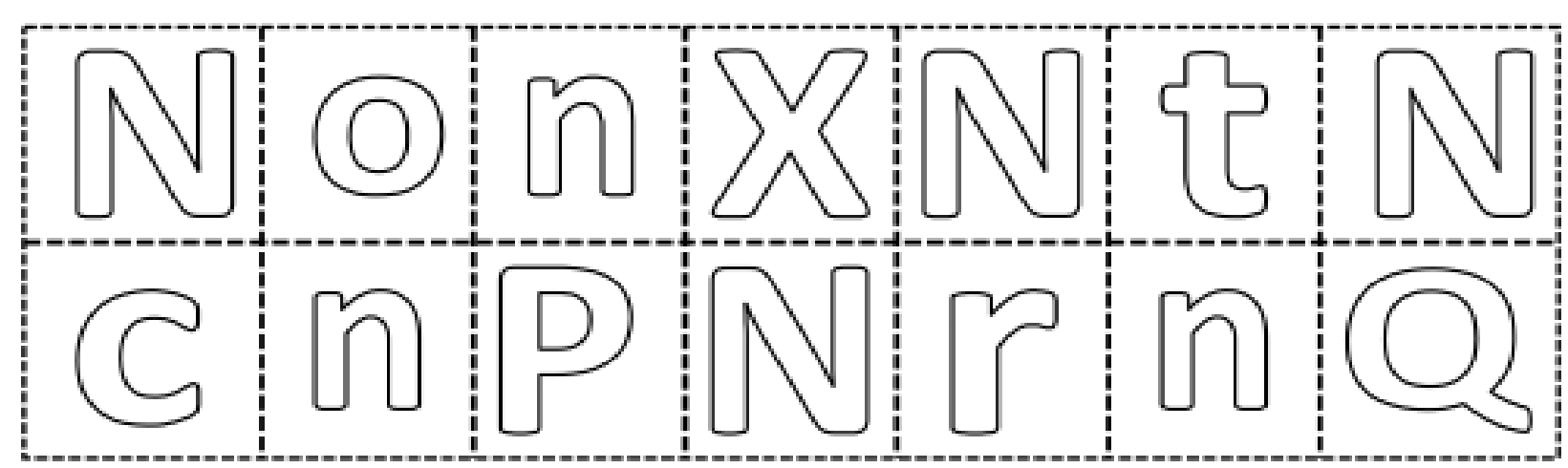


Appendix I

Nn Sound: Cut and Sort

Name:

\section{Sort the pictures}

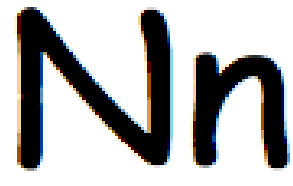

Begins with $\mathrm{N}$

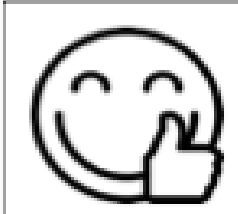

Does not begin with $N$
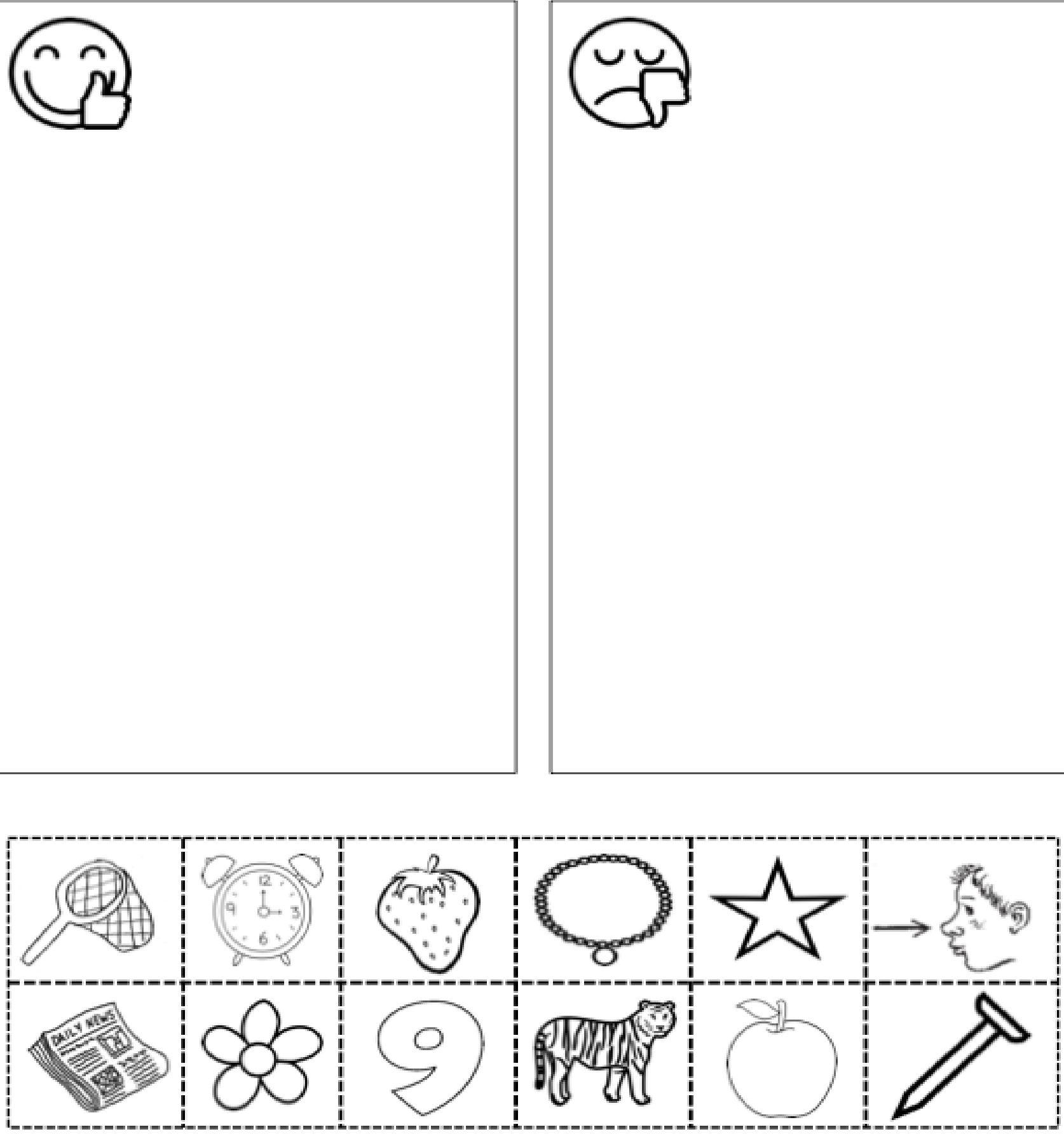
Appendix J

Blend Nn Sound: Read and Circle the Word That Matches to the Picture

Name:

\section{Can Read}

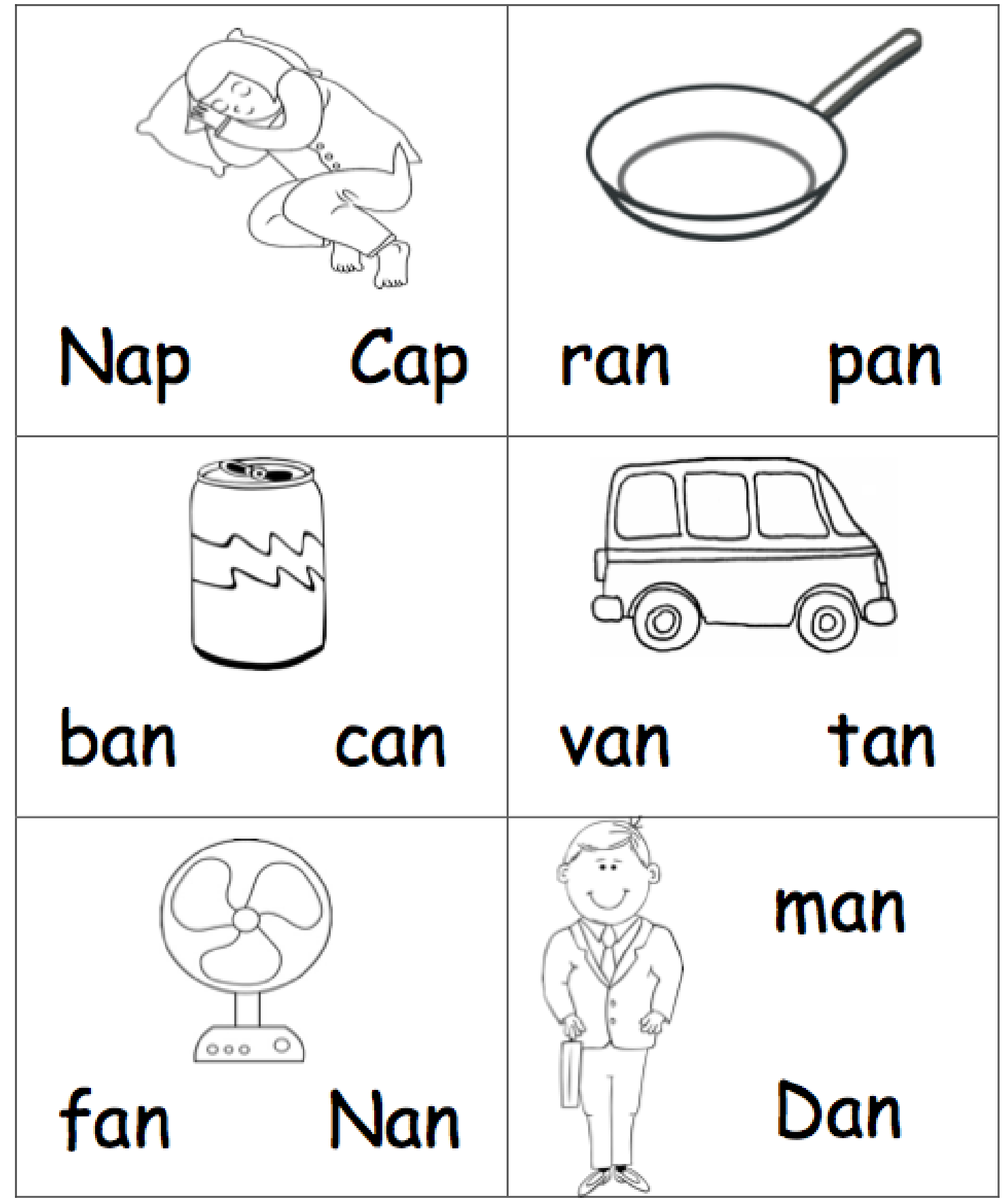


Appendix K

Letter Cc Bracelet

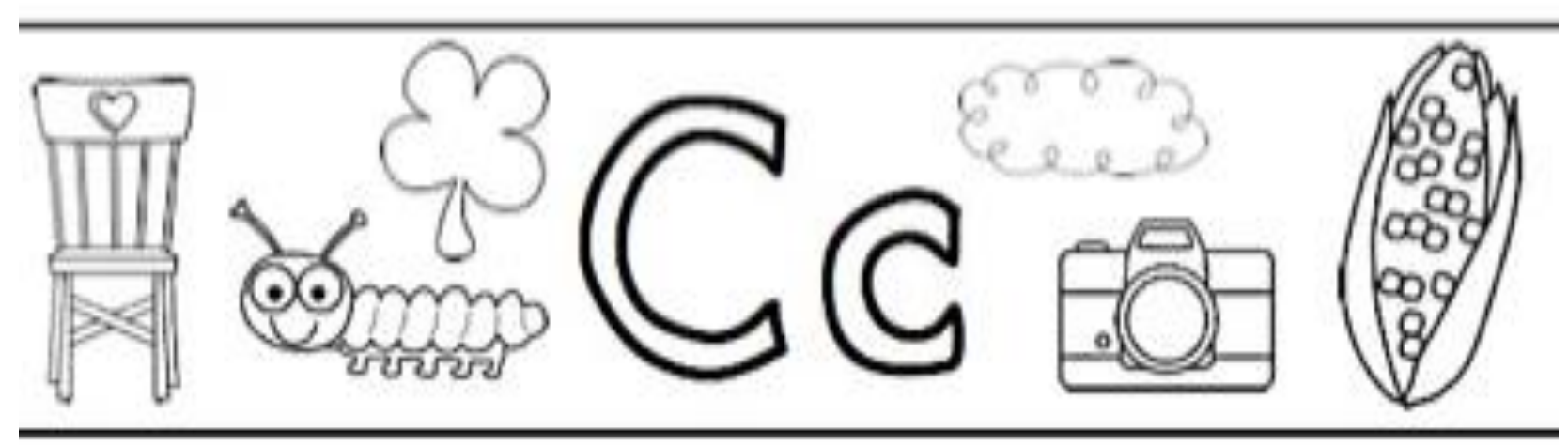

Appendix L

Cc Clip Card

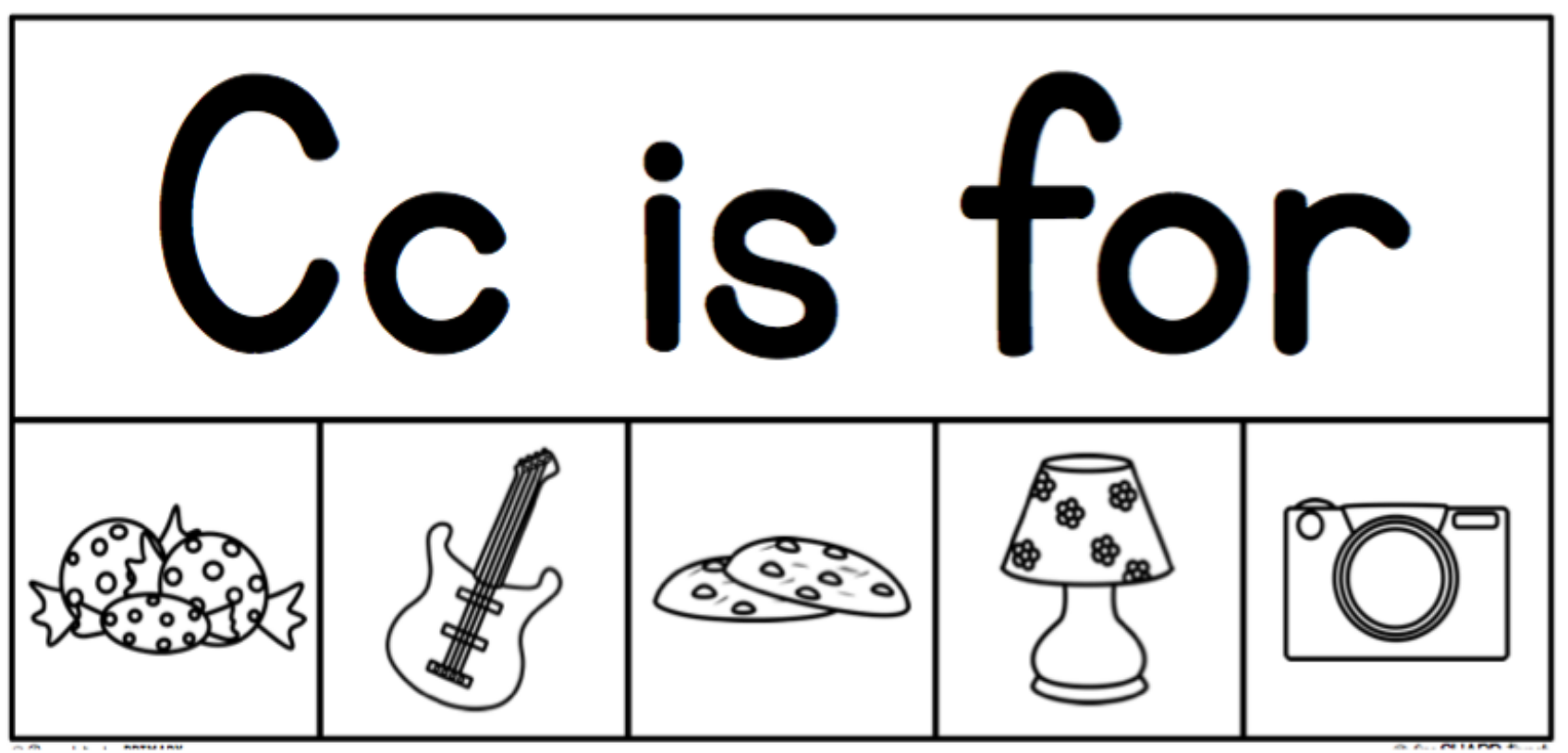


Appendix M

Letter Cc: Read, Cut and Paste

Name:

\section{Read And Match! \\ Cut and paste the pictures}
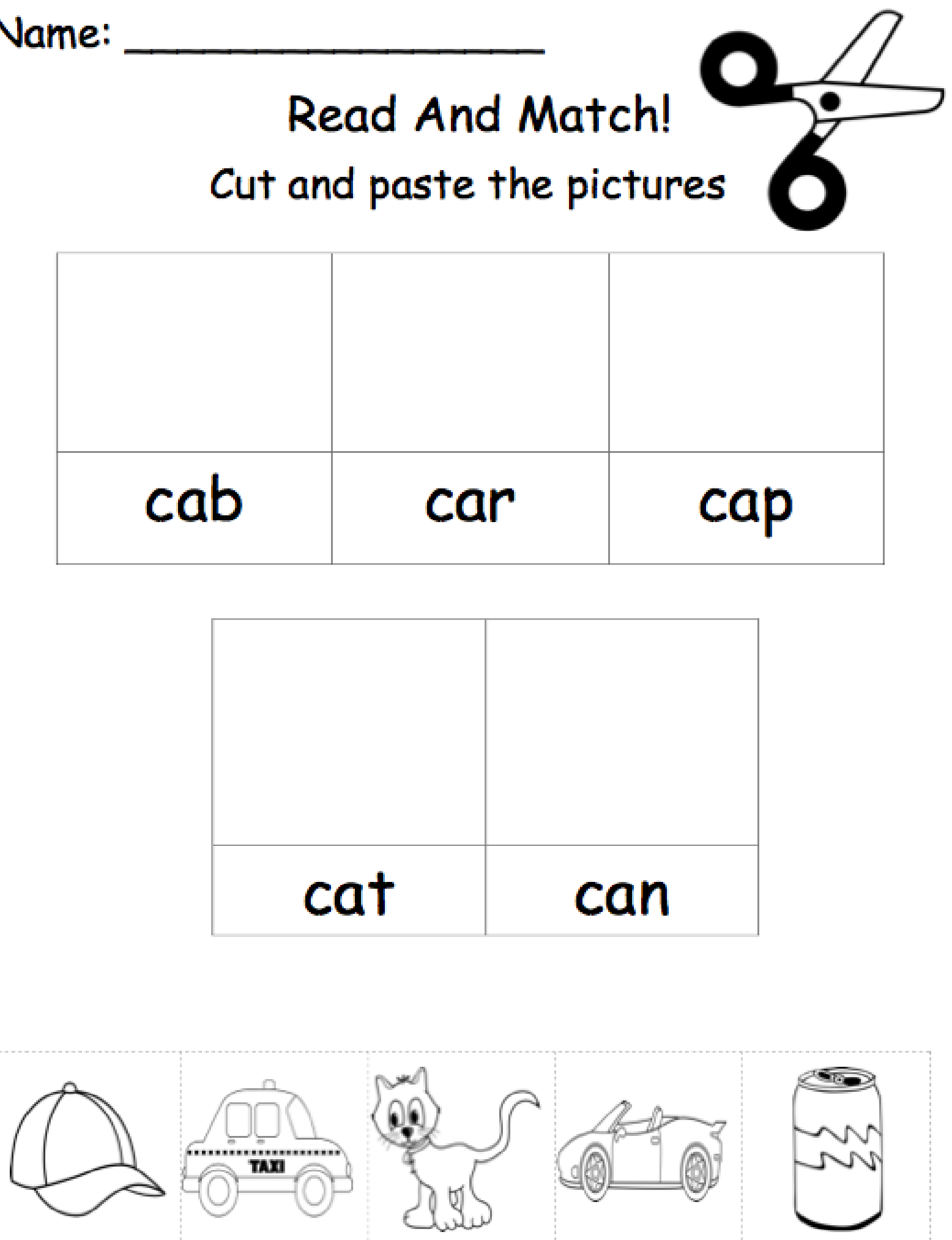
Appendix N

Letter Oo: Flip Book

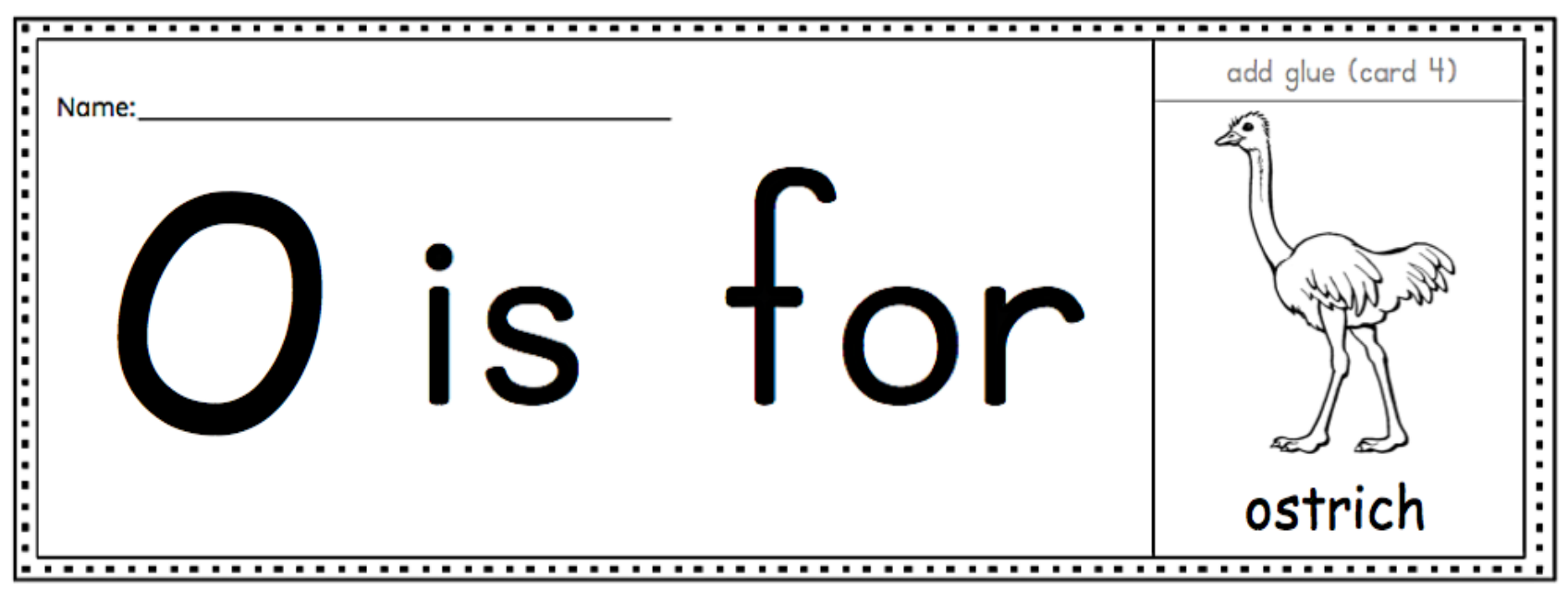

8

Color, cut and glue the cards to make a flipbook.

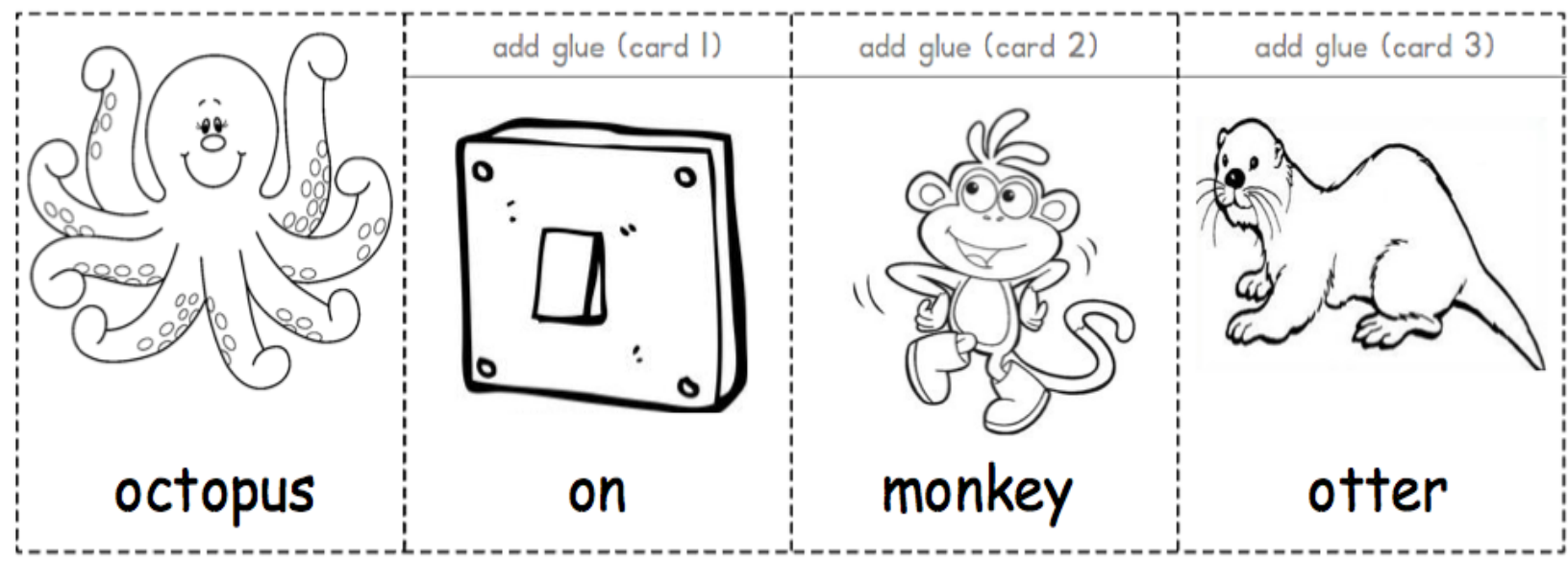


Appendix 0

Letter Oo: Read and Match

Name:

\section{Read and Match}
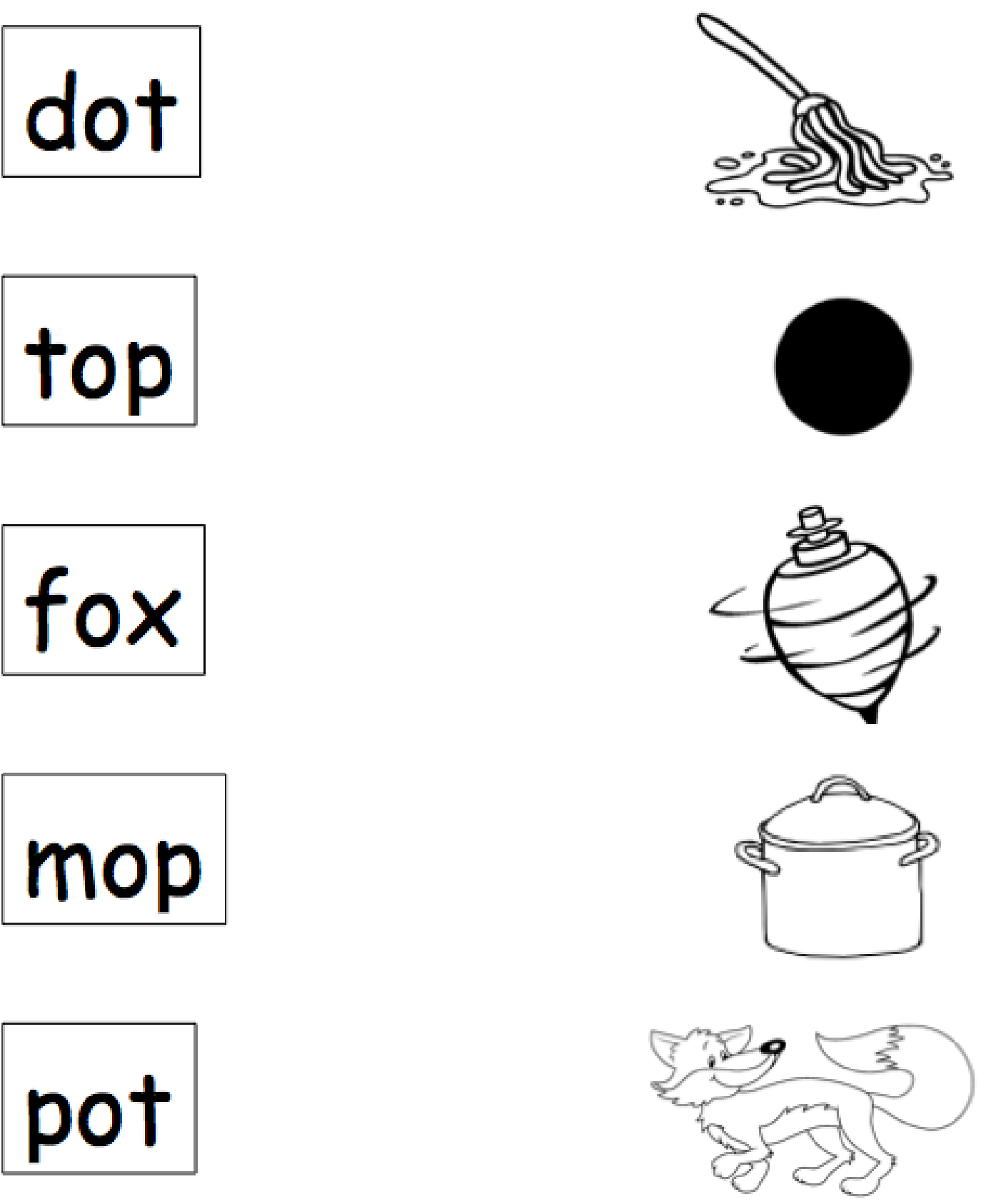
Appendix P

Recording Sheet - Experimental Group

Name-Sound Recording sheet (Experimental Group)

\begin{tabular}{|c|c|c|c|c|c|c|}
\hline \multirow{2}{*}{ Student } & \multicolumn{2}{|c|}{ Letter Nn } & \multicolumn{2}{|c|}{ Letter Cc } & \multicolumn{2}{|c|}{ Letter Oo } \\
\hline & Nome & Sound & Name & Sound & Nome & Sound \\
\hline 1 & 5 & 5 & 5 & 5 & 5 & 5 \\
\hline 2 & 5 & 5 & 5 & 5 & 5 & 5 \\
\hline 3 & 5 & 5 & 5 & 5 & 5 & 5 \\
\hline 4 & 5 & 5 & 5 & 5 & 5 & 5 \\
\hline 5 & 5 & 5 & 5 & 5 & 5 & 5 \\
\hline 6 & 5 & 5 & 5 & 5 & 5 & 5 \\
\hline 7 & 5 & 5 & 5 & 5 & 5 & 5 \\
\hline 8 & 5 & 5 & 5 & 5 & 5 & 5 \\
\hline 9 & 5 & 5 & 5 & 5 & 5 & 5 \\
\hline 10 & 5 & 5 & 5 & 5 & 5 & 5 \\
\hline 11 & 5 & 5 & 5 & 5 & 5 & 5 \\
\hline 12 & 5 & 5 & 5 & 5 & 5 & 5 \\
\hline 13 & 5 & 5 & 5 & 5 & 5 & 5 \\
\hline 14 & 5 & 5 & 5 & 5 & 5 & 5 \\
\hline 15 & 5 & 5 & 5 & 5 & 5 & 5 \\
\hline 16 & 5 & 5 & 5 & 5 & 5 & 5 \\
\hline 17 & 5 & 5 & 5 & 5 & 5 & 5 \\
\hline 18 & 5 & 5 & 5 & 5 & 5 & 5 \\
\hline 19 & 5 & 5 & 5 & 5 & 5 & 5 \\
\hline
\end{tabular}


Appendix Q

Recording Sheet - Control Group

Name-Sound Recording sheet (Control Group)

\begin{tabular}{|c|c|c|c|c|c|c|}
\hline \multirow{2}{*}{ Student } & \multicolumn{2}{|c|}{ Letter Nn } & \multicolumn{2}{|c|}{ Letter $C c$} & \multicolumn{2}{|c|}{ Letter Oo } \\
\hline & Mame & Sound & Name & Sound & Nama & Sound \\
\hline 1 & 5 & 5 & 5 & 5 & 5 & 5 \\
\hline 2 & 5 & 5 & 5 & 5 & 5 & 5 \\
\hline 3 & 5 & 5 & 5 & 5 & 5 & 5 \\
\hline 4 & 5 & 5 & 5 & 5 & 5 & 5 \\
\hline 5 & 5 & 5 & 5 & 5 & 5 & 5 \\
\hline 6 & 5 & 5 & 5 & 5 & 5 & 5 \\
\hline 7 & 5 & 5 & 5 & 5 & 5 & 5 \\
\hline $\mathrm{a}$ & 5 & 5 & 5 & 4 & 5 & 5 \\
\hline 9 & 5 & 5 & 5 & 5 & 5 & 5 \\
\hline 10 & 5 & 5 & 5 & 5 & 5 & 5 \\
\hline 11 & 5 & 5 & 5 & 5 & 5 & 5 \\
\hline 12 & 5 & 5 & 5 & 5 & 5 & 5 \\
\hline 13 & 5 & 5 & 5 & 5 & 5 & 5 \\
\hline 14 & 2 & 5 & 5 & 2 & 5 & 5 \\
\hline 15 & 5 & 5 & 5 & 5 & 5 & 5 \\
\hline 16 & 5 & 5 & 5 & 5 & 5 & 5 \\
\hline 17 & 5 & 5 & 5 & 5 & 5 & 5 \\
\hline 19 & 5 & 5 & 5 & 5 & 5 & 5 \\
\hline 19 & $z$ & 4 & 5 & 5 & 5 & 5 \\
\hline
\end{tabular}

\section{Copyrights}

Copyright for this article is retained by the author(s), with first publication rights granted to the journal.

This is an open-access article distributed under the terms and conditions of the Creative Commons Attribution license which permits unrestricted use, distribution, and reproduction in any medium, provided the original work is properly cited. 